Prepared in cooperation with the U.S. Army Corps of Engineers

\title{
Acoustic Tag Detections of Green Sturgeon in the Columbia River and Coos Bay Estuaries, Washington and Oregon, 2010-11
}

Open-File Report 2017-1144 
Cover: Line drawing of green sturgeon (Acipenser medirostris). By Muséum d'histoire Naturelle - Nouvelles Archives du Muséum d'histoire Naturelle, Public Domain. 


\section{Acoustic Tag Detections of Green Sturgeon in the Columbia River and Coos Bay Estuaries, Washington and Oregon, 2010-11}

By Hal C. Hansel, Jason G. Romine, and Russell W. Perry

Prepared in cooperation with the U.S. Army Corps of Engineers

Open-File Report 2017-1144

U.S. Department of the Interior

U.S. Geological Survey 


\section{U.S. Department of the Interior \\ RYAN K. ZINKE, Secretary}

\section{U.S. Geological Survey \\ William H. Werkheiser, Acting Director}

U.S. Geological Survey, Reston, Virginia: 2017

For more information on the USGS - the Federal source for science about the Earth, its natural and living resources, natural hazards, and the environment-visit https://www.usgs.gov/ or call 1-888-ASK-USGS (1-888-275-8747).

For an overview of USGS information products, including maps, imagery, and publications, visit https:/store.usgs.gov.

Disclaimer: The findings and conclusions in this article are those of the author(s) and do not necessarily represent the views of the U.S. Fish and Wildlife Service.

Any use of trade, firm, or product names is for descriptive purposes only and does not imply endorsement by the U.S. Government.

Although this information product, for the most part, is in the public domain, it also may contain copyrighted materials as noted in the text. Permission to reproduce copyrighted items must be secured from the copyright owner.

Suggested citation:

Hansel, H.C., Romine, J.G., and Perry, R.W., 2017, Acoustic tag detections of green sturgeon in the Columbia River and Coos Bay estuaries, Washington and Oregon, 2010-11: U.S. Geological Survey Open-File Report 2017-1144, 30 p., https://doi.org/10.3133/ofr20171144. 


\section{Contents}

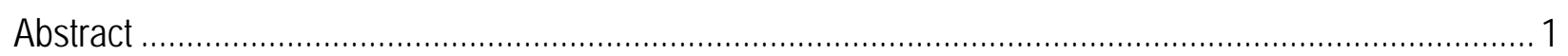

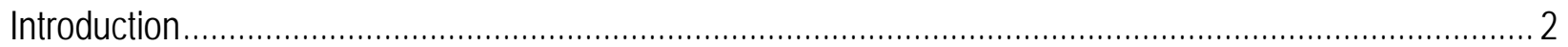

Study Area

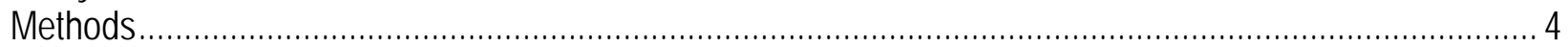

Acoustic Telemetry Detection Array ......................................................................................... 4

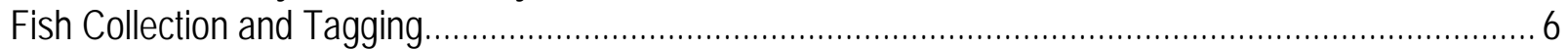

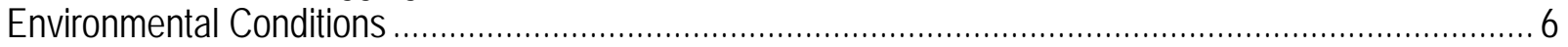

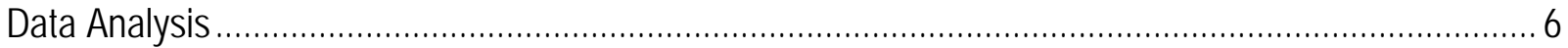

Timing of Ingress and Egress, and Residence Time ............................................................. 7

Extent of Upriver Migration .................................................................................................. 7

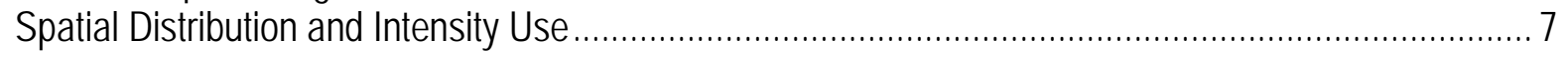

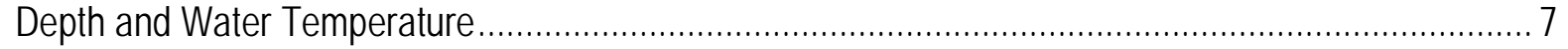

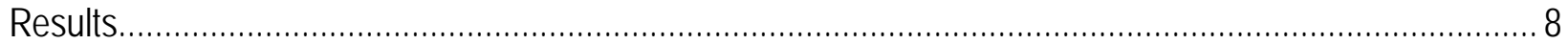

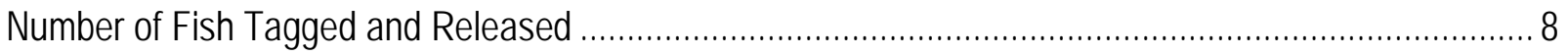

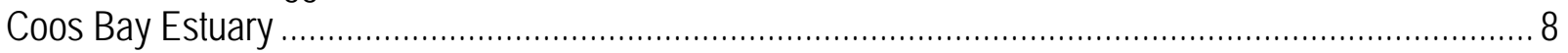

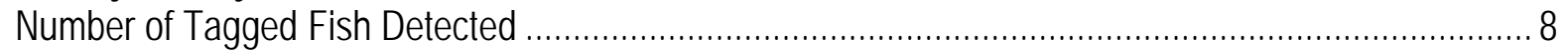

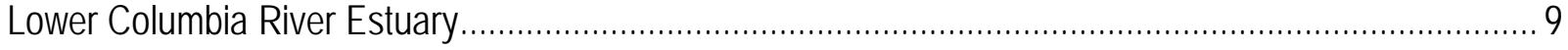

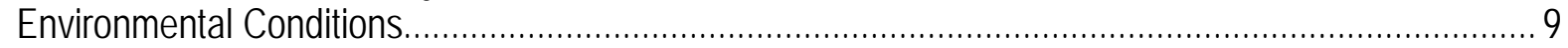

Number of Tagged Fish Detected .................................................................................... 10

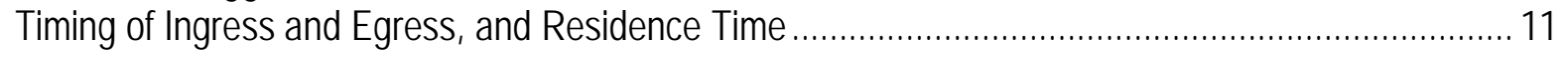

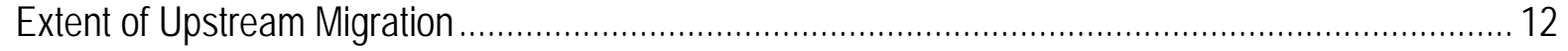

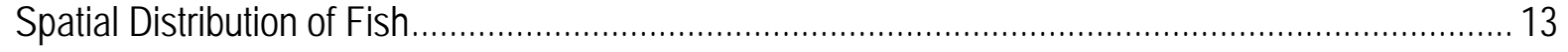

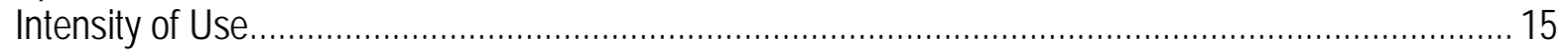

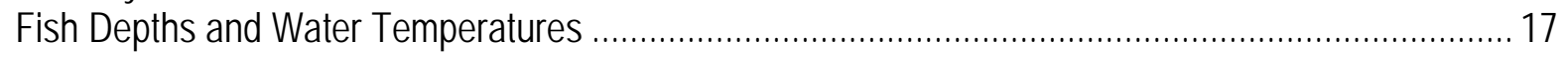

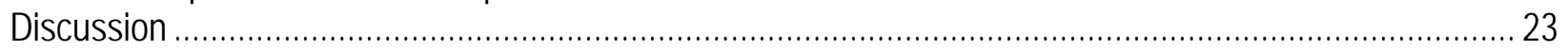

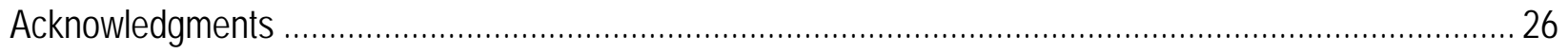

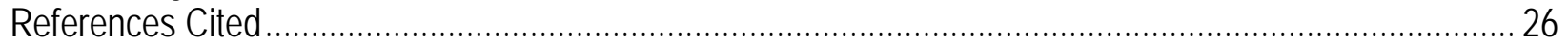

Appendix A. Dates When Acoustic-Receiver Stations in the Detection Array Were Operational in the lower Columbia River Estuary, Washington and Oregon, 2010-11 ................................................. 29

\section{Figures}

Figure 1. Image showing locations and station Nos. of 20 acoustic receivers (circles) deployed from the mouth to river kilometer 21.6 in Coos Bay Estuary, Oregon, 2010 ............................................. 5

Figure 2. Image showing locations and station Nos. of 30 acoustic receivers deployed from the mouth to river kilometer (rkm) 37.8 of the lower Columbia River Estuary, Washington and Oregon, 2010 (blue and green circles) and 2011 (green circles only) .....

Figure 3. Profiles showing median hourly water temperatures (top) and difference between the maximum and minimum daily temperatures (bottom) in degrees Celsius $\left({ }^{\circ} \mathrm{C}\right.$ ) in the lower (river kilometer 4.8) and upper (river kilometer 38) parts of the study area, lower Columbia River Estuary, Washington and Oregon, 2010. 
Figure 4. Graphs showing number of acoustic-tagged green sturgeon entering, leaving, and inhabiting the lower Columbia River Estuary by month, Washington and Oregon, 2010-11 ..................... 12

Figure 5. Graph showing extent of upriver migration by acoustic-tagged green sturgeon in the lower Columbia River Estuary, Washington and Oregon, 2010-11

Figure 6. Image showing number of individual acoustic-tagged green sturgeon detected at receiver stations in the lower Columbia River Estuary, Washington and Oregon, 2010 14

Figure 7. Image showing number of individual acoustic-tagged green sturgeon detected at receiver stations in the lower Columbia River Estuary, Washington and Oregon, 2011

Figure 8. Image showing number of acoustic-tagged green sturgeon detections at receiver stations in the lower Columbia River Estuary, Washington and Oregon, 2010

Figure 9. Image showing number of acoustic-tagged green sturgeon detections at receiver stations in the lower Columbia River Estuary, Washington and Oregon, 2011

Figure 10. Boxplots showing fish depths below the water surface (top) and water temperatures (bottom) inhabited by fish No. 2635 in the lower Columbia River Estuary, Washington and Oregon, August 31-September 2, 2010

Figure 11. Boxplots showing fish depths below the water surface inhabited by fish No. 2661 in the lower Columbia River Estuary, Washington and Oregon, September 8-October 10, 2010.

Figure 12. Boxplots showing fish depths below the water surface (top) and water temperatures (bottom) inhabited by fish number 2635 in the lower Columbia River Estuary, Washington and Oregon, June 13-August 30, 2011.

Figure 13. Boxplots showing fish depths below the water surface (top) and water temperatures inhabited by fish No. 2656 in the lower Columbia River Estuary, Washington and Oregon, July $20-$ July $31,2011$.

Figure 14. Boxplots showing fish depths below the water surface (top) and water temperatures inhabited by fish Nos. 2648, 2632, 2644, and 2646 at station 150 in the lower Columbia River Estuary, Washington and Oregon, 2011.

\section{Tables}

Table 1. Summary statistics for green sturgeon tagged and released, Washington and Oregon, 2010-11.

Table 2. Summary statistics for green sturgeon detected in the lower Columbia River Estuary, Washington and Oregon, 2010-11 


\section{Conversion Factors}

\begin{tabular}{|c|c|c|}
\hline Multiply & By & To obtain \\
\hline \multicolumn{3}{|c|}{ Length } \\
\hline millimeter (mm) & 0.03937 & inch (in.) \\
\hline centimeter (cm) & 0.3937 & inch (in.) \\
\hline meter $(\mathrm{m})$ & 3.281 & foot $(\mathrm{ft})$ \\
\hline kilometer (km) & 0.6214 & mile (mi) \\
\hline \multicolumn{3}{|c|}{ Area } \\
\hline square kilometer $\left(\mathrm{km}^{2}\right)$ & 0.3861 & square mile $\left(\mathrm{mi}^{2}\right)$ \\
\hline square kilometer $\left(\mathrm{km}^{2}\right)$ & 247.1 & acre \\
\hline \multicolumn{3}{|c|}{ Volume } \\
\hline cubic meter $\left(\mathrm{m}^{3}\right)$ & 264.2 & gallon (gal) \\
\hline \multicolumn{3}{|c|}{ Mass } \\
\hline gram (g) & 0.03527 & ounce, avoirdupois (oz) \\
\hline kilogram (kg) & 2.205 & pound avoirdupois (lb) \\
\hline
\end{tabular}

Temperature in degrees Celsius $\left({ }^{\circ} \mathrm{C}\right)$ may be converted to degrees Fahrenheit $\left({ }^{\circ} \mathrm{F}\right)$ as follows: ${ }^{\circ} \mathrm{F}=\left(1.8 \times{ }^{\circ} \mathrm{C}\right)+32$.

\section{Datum}

Geographic coordinates (latitude/longitude) referenced to the World Geodetic System Datum of 1984 (WGS84).

\section{Abbreviations}

$\begin{array}{ll}\text { bws } & \text { below water surface } \\ \text { DPS } & \text { Distinct Population Segment } \\ \text { ESA } & \text { Endangered Species Act } \\ \text { FL } & \text { fork length } \\ \text { rkm } & \text { river kilometer } \\ \text { NMFS } & \text { National Marine Fisheries Service } \\ \text { NOAA } & \text { National Oceanic and Atmospheric Administration } \\ \text { USACE } & \text { U.S. Army Corps of Engineers } \\ \text { Reclamation } & \text { Bureau of Reclamation } \\ \text { TL } & \text { total length } \\ \text { USGS } & \text { U.S. Geological Survey }\end{array}$


This page left intentionally blank 


\title{
Acoustic Tag Detections of Green Sturgeon in the Columbia River and Coos Bay Estuaries, Washington and Oregon, 2010-11
}

By Hal C. Hansel${ }^{1}$, Jason G. Romine ${ }^{2}$, and Russell W. Perry ${ }^{1}$

\begin{abstract}
The Columbia River, in Washington and Oregon, and Coos Bay, in Oregon, are economically important shipping channels that are inhabited by several fishes protected under the Endangered Species Act (ESA). Maintenance of shipping channels involves dredge operations to maintain sufficient in-channel depths to allow large ships to navigate the waterways safely. Fishes entrained by dredge equipment often die or experience delayed mortality. Other potential negative effects of dredging include increased turbidity, reductions in prey resources, and the release of harmful contaminants from the dredged sediments. One species of concern is the ESA-listed green sturgeon (Acipenser medirostris; Southern Distinct Population Segment). In this study, we used acoustic telemetry to identify habitat use, arrival and departure timing, and the extent of upstream migration of green sturgeon in the Columbia River and Coos Bay to help inform dredge operations to minimize potential take of green sturgeon. Autonomous acoustic receivers were deployed in Coos Bay from the mouth to river kilometer (rkm) 21.6 from October 2009 through October 2010. In the Columbia River Estuary, receivers were deployed between the mouth and rkm 37.8 from April to November in 2010 and 2011. A total of 29 subadult and adult green sturgeon were tagged with temperature and pressure sensor tags and released during the study, primarily in Willapa Bay and Grays Harbor, Washington, and the Klamath River, Oregon. Green sturgeon detected during the study but released by other researchers also were included in the study.

The number of tagged green sturgeon detected in the two estuaries differed markedly. In Coos Bay, only one green sturgeon was detected for about 2 hours near the estuary mouth. In the Columbia River Estuary, 9 green sturgeon were detected in 2010 and 10 fish were detected in 2011. Green sturgeon entered the Columbia River from May through October during both years, with the greatest numbers of fish being present in August and September. One green sturgeon was detected at the uppermost receiver station (rkm 37.8), but overall, the number of fish detected upriver decreased rapidly with distance from the estuary mouth. Residence times of fish that were only detected in the lower $4.8 \mathrm{rkm}$ generally were less than 24 hours, but fish detected farther upriver had a median residence time greater than 10 days. Green sturgeon were widely dispersed among channel and
\end{abstract}

${ }^{1}$ U.S. Geological Survey.

${ }^{2}$ U.S. Fish and Wildlife Service. 
non-channel habitats in the lower estuary in 2010. In 2011, the fish were more concentrated near the estuary mouth. The intensity of use, measured as the total number of fish detections at each station, generally was greatest from Point Ellice (rkm 20.1) to Rice Island (rkm 33.0) in channel and shallow shoal areas, and lowest at the stations west of Point Ellice with the exception of the area near the entrance to the Ilwaco Channel.

Sensor tag data indicated that the deeper South and North Channel habitats (bottom depth $\geq 10 \mathrm{~m}$ ) were used, as were the more shallow sandy shoal, shoreline, and bay habitats (bottom depth $<10 \mathrm{~m}$ ). Median fish depths among fish and receiver locations ranged from 2.5 to $28.2 \mathrm{~m}$ below water surface (bws) and water temperatures ranged from 9.1 to $22.0^{\circ} \mathrm{C}$ during late May through midOctober. In the deeper channel habitat, near the Ilwaco Channel, fish inhabited water with median temperatures ranging from 11.4 to $16.7^{\circ} \mathrm{C}$, whereas east of Point Ellice, predominantly in shallow non-channel habitats, fish inhabited water with median temperatures ranging from about 17.0 to $21.0{ }^{\circ} \mathrm{C}$.

\section{Introduction}

Waterborne commerce in the Columbia River, Washington and Oregon, and Coos Bay, Oregon, through the federally maintained navigation channels has provided many economic benefits to the Pacific Northwest and the Nation, particularly the efficient transportation of bulk domestic and international commodities by large ships. Since the first dredging operations in the late 1800s, the U.S. Army Corps of Engineers (USACE), has intermittently deepened and maintained these channels to meet the needs of increasingly larger and deeper draft cargo ships. The most recent deepening project, the Columbia River Channels Improvement Project, began in 2005 and was completed in 2010. It authorized the USACE to increase the 182.9-m-wide navigation channel from 12.2 to $13.1 \mathrm{~m}$ in depth between the mouth of the river (river kilometer [rkm] 4.8) and Portland, Oregon (rkm 171.4). The Project also included a 50-year maintenance period to maintain the channel at that depth through annual or semi-annual removal of the sandy shoals that rapidly form because of sediment deposition. Most shoaling occurs during the period immediately following the annual freshet in early summer, and dredges are used to remove these shoals before low water levels in autumn. From 2011 to 2014, maintenance dredging averaged about 5.4 million $\mathrm{m}^{3}$ of dredged materials per year (U.S. Army Corps of Engineers, 2015). The USACE currently maintains the Coos Bay navigation channel at a depth of $14.3 \mathrm{~m}$ from the entrance to rkm 1.6, and at a depth of $11.3 \mathrm{~m}$ from rkms 1.6 to 24.1.

The Columbia River and Coos Bay Estuaries, through which the navigation channels pass, support many aquatic and terrestrial wildlife species. Hence, deepening and maintenance operations in the navigation channels are under the purview of environmental laws, including the Endangered Species Act (ESA), Magnuson-Stevens Fishery Conservation and Management Act, Clean Water Act, and National Environmental Policy Act. Common issues raised with dredging include increased turbidity, destruction of critical habitat, release of harmful contaminants from dredged sediments, negative effects on prey resources, and entrainment of fishes leading to mortality. As part of the initial planning and approval process for deepening the Columbia River channel and the continuing operations and maintenance, the USACE worked with the National Marine Fisheries Service (NMFS) and the U.S. Fish and Wildlife Service to resolve issues of concern in the original biological opinions, as well as to address new biological information. Listed endangered and threatened salmonids were the primary fish species focused on prior to the approval of the proposed Columbia River Channel Improvement Project in 2004. However, not long after the initial dredging for the project began, the Southern Distinct Population Segment (DPS) of the North American green sturgeon (Acipenser medirostris) was designated as threatened by the National Oceanic and Atmospheric Administration (NOAA) in 2006 (National Oceanic and Atmospheric Administration, 2006). 
The green sturgeon is the most marine-oriented member of the sturgeon family, with a current range extending along the Pacific Coast from Baja California, Mexico, to the Bearing Sea (Miller and Lea, 1972; Moyle, 2002; Colway and Stevenson, 2007; Rosales-Casian and Almeda-Jaurui, 2009). Two distinct population segments of the green sturgeon are currently recognized by the NMFS under the ESA guidelines. The Southern DPS spawns primarily in the Sacramento River in California, whereas the Northern DPS consists of fish that spawn in the Klamath and Rogue Rivers in California and Oregon, respectively. The Northern DPS is not threatened, but the NMFS recognizes it as a species of concern (National Oceanic and Atmospheric Administration, 2014). Critical habitat for the Southern DPS was designated in 2009 (National Oceanic and Atmospheric Administration, 2009).

Juvenile green sturgeon migrate to the ocean after rearing in freshwater for 1-4 years (Adams and others, 2007). Subadults move predominantly north from their natal rivers along the coasts of Oregon and Washington, together with non-spawning adults (Erickson and Hightower, 2007; Lindley and others, 2008, 2011). The subadults and non-spawning adults also congregate during summer and autumn in bays and estuaries in Oregon and Washington, and near Vancouver Island where fish are believed to overwinter (Adams and others, 2007; Moser and Lindley, 2007; Lindley and others, 2008, 2011). Green sturgeon that congregate in the Columbia River Estuary consist of fish from both the Southern and Northern DPSs (Israel and others, 2004, 2009; Moser and Lindley, 2007; Lindley and others 2011; Schreier and others, 2016), and inhabit the estuary between late spring and early autumn (Moser and Lindley, 2007; Parsley, 2009; Lindley and others, 2011). Less information is available, however, concerning the seasonal ingress and egress of individual fish, variation in individual residence times, spatial use and extent of upstream movement, and depths and water temperatures inhabited along the navigation channels in Coos Bay and the lower Columbia River despite the commercial and incidental harvest of green sturgeon prior to being listed under the ESA (Beamesderfer and Webb, 2002). Lindley and others (2011) reported minimal use of the Coos Bay Estuary by green sturgeon. More information is needed to manage and regulate the various human activities that occur in the in the lower Columbia River Estuary and that may negatively affect green sturgeon.

The USACE primarily is concerned with how its continued dredging operations in the Federal navigation channels (as well as the dredging proposed by others that they regulate through a permit process) may affect green sturgeon. To this end, the USACE Portland District previously partnered with the U.S. Geological Survey (USGS) Western Fisheries Research Center in 2009 to conduct research evaluating the habitat use of green sturgeon along the navigation channels and localized areas adjacent to the channels in the lower Columbia River and Coos Bay using acoustic telemetry methods. Funding was not provided to accomplish reporting at that time, but was recently made available to report on certain aspects of the work. Our objective is to provide additional information on green sturgeon behavior in the Columbia River Estuary in the following areas:

- Dates of ingress and egress,

- Extent of upstream migration,

- Variability in individual residence times,

- General fish use of areas in and adjacent to the navigation channel and non-navigation channel areas in the lower $38 \mathrm{rkm}$ of the estuary,

- Variability in fish depths and water temperatures at the locations where fish were detected, and

- The range of environmental variables during the time the green sturgeon inhabited the estuary. 


\section{Study Area}

This study focused on green sturgeon habitat use in Coos Bay, Oregon, and the lower Columbia River, Oregon and Washington. Both estuaries are listed as critical habitat for the Southern DPS of green sturgeon (National Oceanic and Atmospheric Administration, 2009). Coos Bay is a small estuary with a water surface area of $34 \mathrm{~km}^{2}$ (Monaco and others, 1992) in southern Oregon about 320 $\mathrm{km}$ south of the Columbia River. Nearly one-half of Coos Bay is tidal, with a mean tidal range of about $1.5 \mathrm{~m}$, and fluctuations from freshwater to saltwater are common (Rumrill, 2006). Coos Bay is commercially important because of exports of wood products and coal from the surrounding area, and is the largest coastal deep-draft harbor between San Francisco Bay and Puget Sound. The navigation channel bisects the system in the lower estuary and runs on the western side of the upper estuary.

The Columbia River is the largest river in the Pacific Northwest (Kammerer, 1990). The lower Columbia River consists of narrow channels separated by wide sand flats, heavily altered by jetties, dikes, and dredging activities (Sherwood and others, 1990). The maintained navigation channel (South Channel) runs along the southern edge of the estuary. The North Channel is not maintained and has been altered by increased sediment loads (Sherwood and others, 1990).

\section{Methods}

\section{Acoustic Telemetry Detection Array}

Vemco $^{\text {TM }}$ VR2W autonomous data-logging acoustic receivers were used at locations alongside the navigation channels and in adjacent habitat areas where green sturgeon might be expected to occur in the Coos Bay and lower Columbia River Estuaries to monitor previously tagged green sturgeon. The receivers recorded the time, date, and depth, and temperature sensor data, if present, for fish within the range of detection. Twenty receivers were deployed in Coos Bay from the mouth of the estuary to about $21.6 \mathrm{~km}$ upstream from October 2009 through October 2010 (fig. 1). The receivers were positioned in a manner to optimize detections in the navigation channel and adjacent areas.

Thirty acoustic receivers were deployed in the Columbia River Estuary from the mouth to about rkm 37.8 from April to November 2010 (fig. 2). The receivers were arranged to detect green sturgeon use of the maintained South Channel, the unmaintained North Channel, shallow shoals, and bays. Most, but not all, receivers were located where the bathymetry was variable and the deeper channel and shallow shoal habitats interfaced. The receivers were installed during April 12-14, 2010, except for stations 152, 151, and 122, which were not deployed until May 14, May 30, and June 28, respectively. Two additional receivers also were deployed upriver, near Gull Island, at about rkm 88 from July 19, 2010, through December 3, 2010. The receivers were downloaded at about 2-month intervals. In 2011, funding was not available for redeploying the receivers. However, 14 of the receivers were installed at the 2010 locations as part of a salmon study conducted by NMFS personnel and green sturgeon detections were made available to the USGS. Two additional receivers were located upriver near Kalama, Washington, at about rkm 72.

The receivers were moored using a 1.27-cm-diameter polypropylene line leading to 0.95-cm galvanized chain, and attached to a 10-14 kg Bruce-style anchor. A Sealite ${ }^{\circledR}$ SLB-600 buoy or a series of crab floats with a Norwegian buoy in the center of the string were used to suspend the mooring. The receiver was oriented downward and secured to the mooring line with heavy-duty cable ties about 3.5 $\mathrm{m}$ beneath the float. 


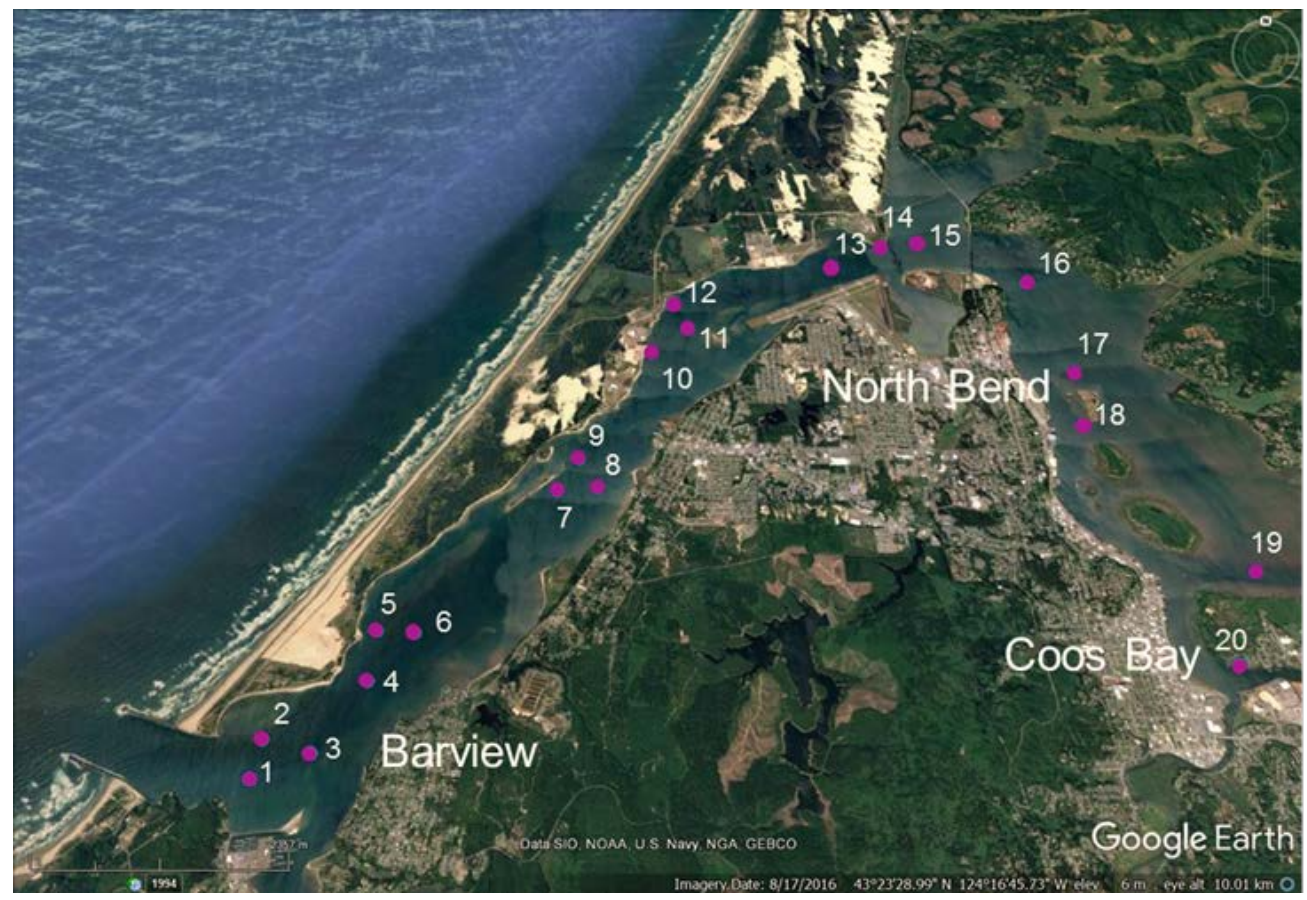

Figure 1. Image showing locations and station Nos. of 20 acoustic receivers (circles) deployed from the mouth to river kilometer 21.6 in Coos Bay Estuary, Oregon, 2010. Image source: Google Earth ${ }^{\mathrm{TM}}$, Scripps Institution of Oceanography, National Oceanic and Atmospheric Administration, U.S. Navy, National Geospatial-Intelligence Agency, General Bathymetric Chart of the Oceans.

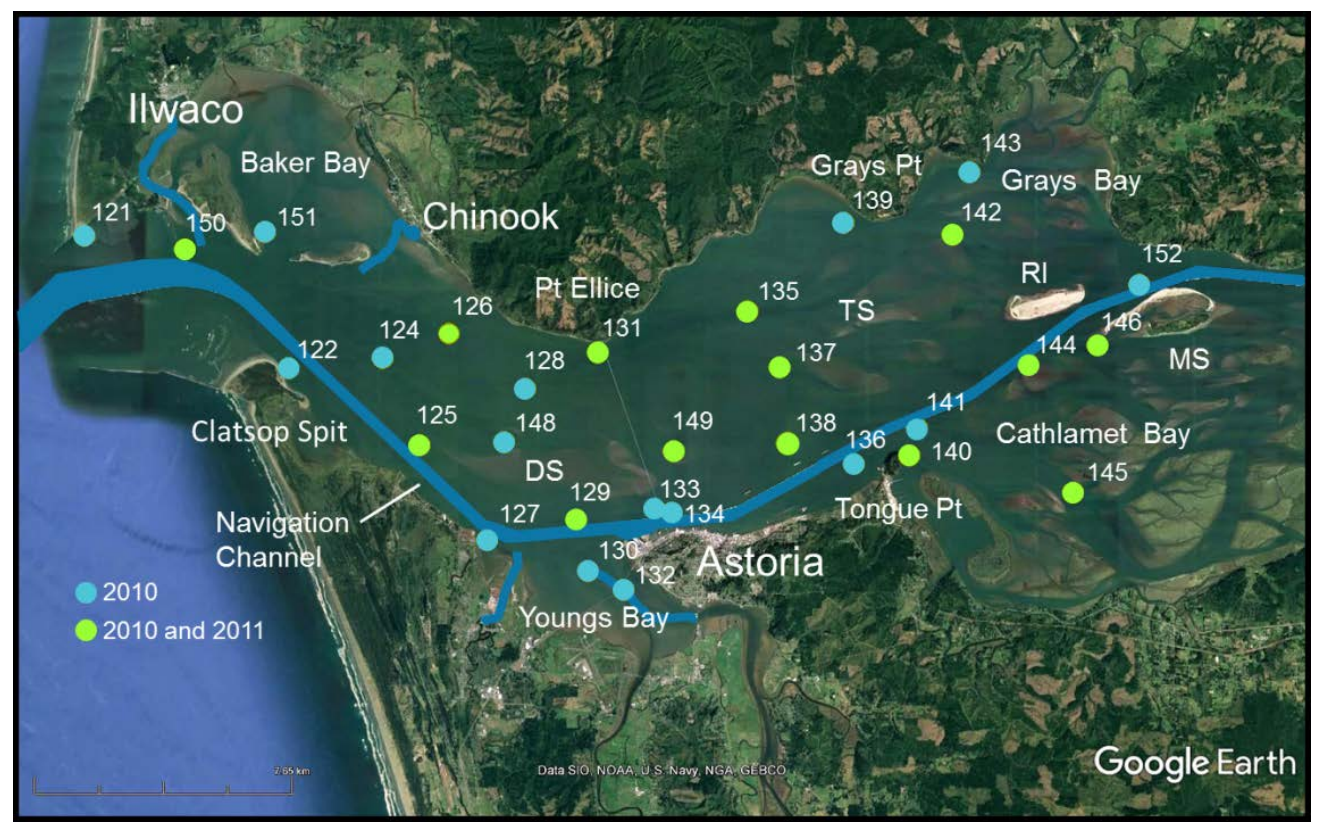

Figure 2. Image showing locations and station Nos. of 30 acoustic receivers deployed from the mouth to river kilometer (rkm) 37.8 of the lower Columbia River Estuary, Washington and Oregon, 2010 (blue and green circles) and 2011 (green circles only). The Columbia River Navigation Channel is shown with a solid blue line, along with smaller navigation channels providing access to llwaco and Chinook, Washington, and Youngs Bay, Oregon. DS, Desdemona Sands; Pt, Point; TS, Taylor Sands; RI, Rice Island; MS, Miller Sands. Image source: Google Earth $^{\text {TM }}$, Scripps Institution of Oceanography, National Oceanic and Atmospheric Administration, U.S. Navy, National Geospatial-Intelligence Agency, General Bathymetric Chart of the Oceans. 
Range testing was conducted to determine the detection capabilities of the acoustic receivers. Noise in the underwater environment caused by various sources can impair the ability of acoustic telemetry systems to detect, decode, and record information from transmitters. Vemco ${ }^{\mathrm{TM}}$ test tags (V166L-A69-1303), set to ping at 5-min intervals, were moored at distances upriver, downriver, and perpendicular to the receiver. The tags were left in place for about 24 hours to determine the effects of tidal fluctuations on detection range. The tags were secured about $3 \mathrm{~m}$ above the anchor on the mooring line with cable ties. The results of this testing indicated that each acoustic receiver had an approximate $600-\mathrm{m}$ radius of effective coverage.

\section{Fish Collection and Tagging}

Green sturgeon were captured with gill nets in the lower Columbia River, Willapa Bay, and Grays Harbor by the Washington Department of Fish and Wildlife or the NMFS, and in the Klamath River by the Yurok Tribe Fisheries Program. Nets were set and fished for 1 hour. Green sturgeon were removed and measured to the nearest millimeter fork length (FL) or total length (TL), and were surgically implanted with a uniquely coded transmitter using the techniques of Moser and Lindley (2007). Fish greater than $1 \mathrm{~m}$ TL were tagged with a VEMCO ${ }^{\mathrm{TM}} \mathrm{V} 16 \mathrm{TP}-6 \mathrm{~L}-9002$ (V16), $69 \mathrm{kHz}$, transmitter equipped with temperature and pressure sensors, whereas fish less than $1 \mathrm{~m}$ in TL were tagged with a VEMCO ${ }^{\mathrm{TM}} \mathrm{V} 13 \mathrm{P}-9002$ (V13), $69 \mathrm{kHz}$, transmitter with only the pressure sensor. The V16 tags were $16 \mathrm{~mm}$ in diameter and $98 \mathrm{~mm}$ long, and weighed $17.3 \mathrm{~g}$ in water. The V13 tags were $13 \mathrm{~mm}$ in diameter, $30 \mathrm{~mm}$ long, and weighed $6 \mathrm{~g}$ in water. After release, tags were tested for functionality using a VEMCO ${ }^{\mathrm{TM}} \mathrm{V} 100$ hydrophone. In addition to data obtained from fish tagged for this study, green sturgeon tagged in independent studies conducted by Federal, State, or Tribal entities in California, Oregon, and Washington also were integrated in the dataset when detected.

\section{Environmental Conditions}

Temperature data loggers (Solinst Levelogger ${ }^{\circledR} \mathrm{Jr}$. M5) were installed in stilling basins near the navigation channel. In the Columbia River, one recorder was located near rkm 4.8, and the other was located at about rkm 38. The loggers were programmed to record at 15-min intervals. Data loggers were inspected and downloaded concurrently with the acoustic receivers. Vendor-provided software was used to maintain and summarize temperature data. Data loggers were not deployed in 2011.

\section{Data Analysis}

Data downloaded from the acoustic receivers were stored and uploaded to the Vemco ${ }^{\mathrm{TM}}$ User Environment (VUE) to maintain and summarize acoustic detections in season. Data were exported for further analysis for use in R (R Core Team, 2017). Data were processed to remove false-positive records prior to analysis. False-positive records indicate that a transmitter was detected when it was not truly present and are common in telemetry systems (Beeman and Perry, 2012). Detection records not having (1) a valid tag code of a green sturgeon released by the USGS or another researcher, (2) at least one other detection within $30 \mathrm{~min}$, and (3) a detection timestamp after the time of release for a fish were excluded from analyses. 


\section{Timing of Ingress and Egress, and Residence Time}

Data were analyzed to determine the number of tagged green sturgeon entering, leaving, and inhabiting the Coos Bay and Columbia River Estuaries each month. The first and last detection dates for an individual were considered the time of ingress and egress. When a fish had a gap in its detection history between the first and last detections, and was not detected in a particular month, it was still counted as being present for that month. Residence time was calculated as the difference between the time of first and last detections in days.

\section{Extent of Upriver Migration}

The extent of upriver migration by individual tagged green sturgeon in the lower $38 \mathrm{rkm}$ was estimated as the difference between the distance to the farthest upriver receiver where the fish was detected and the river mouth at rkm 0 . The minimum, maximum, and median distances green sturgeon migrated upriver were calculated. The number of individual tagged green sturgeon detected compared to the distance upriver was plotted to determine the distribution of tagged green sturgeon with increased distance from the mouth to the farthest receiver station upriver.

\section{Spatial Distribution and Intensity Use}

The number of green sturgeon detected at each receiver station was used to determine the distribution of tagged green sturgeon in the lower estuary among stations located adjacent to the southern navigation channel, the unmaintained North Channel, shallow shoal areas, and bays. The number of total detections at each receiver was used to estimate the intensity of use among estuary areas.

\section{Depth and Water Temperature}

Water depths inhabited by green sturgeon and associated water temperatures were determined from the subset of tagged fish with transmitters equipped with depth and water temperature sensors. Fish-depth data were used to assign fish detections to deeper channel habitats characteristic of the maintained South Channel, the unmaintained North Channel, and the shallow non-channel habitat in the shoals and bays adjacent to them. Detections of fish at depths less than $10 \mathrm{~m}$ bws were considered to be in shallow non-channel habitats outside the deeper channels, whereas detections of fish at depths greater than or equal to $10 \mathrm{~m}$ bws were considered to be in the deep channel habitat. The number of detections in the channels was considered a conservative estimate of channel habitat use because some of the detections at depths less than $10 \mathrm{~m}$ bws could also have occurred when a fish was in one of the channels in the upper $10 \mathrm{~m}$ of the water column. The distribution of depths inhabited by fish was examined graphically at each station using boxplots to determine the pattern of use of channel and non-channel habitats among stations. Data obtained from the temperature sensors were used to graphically examine the variability in water temperatures among stations and habitats where green sturgeon were detected. 


\section{Results}

\section{Number of Fish Tagged and Released}

In 2010, 25 green sturgeon were tagged and released from May 10 through September 16 (table 1). Most of these fish were captured in Willapa Bay, Grays Harbor, and the Klamath River. Only one fish was tagged and released in the lower Columbia River. The mean length was 1.84 m (range 1.69$2.18 \mathrm{~m}$ ) TL for the Klamath River fish, and $1.46 \mathrm{~m}$ (range 1.23-1.84 m) and 1.48 m (range 1.32-1.73 m) FL for the Willapa Bay and Grays Harbor fish, respectively. The single Columbia River fish was $0.98 \mathrm{~m}$ FL. These fish likely were all subadults and adults ( $>0.75 \mathrm{~m} \mathrm{TL})$. An additional four fish were tagged and released in Grays Harbor from June 8 through July 8, 2011. These fish generally were smaller than the fish released in 2010, with a mean FL of $0.99 \mathrm{~m}$ (range $0.92-1.13 \mathrm{~m}$ ).

Table 1. Summary statistics for green sturgeon tagged and released, Washington and Oregon, 2010-11.

[N, number of fish; SD, standard deviation; Na, not applicable]

\begin{tabular}{|c|c|c|c|c|c|c|c|}
\hline \multirow{2}{*}{ Year } & \multirow{2}{*}{ Release site } & \multicolumn{5}{|c|}{ Fish length (meters) } & \multirow{2}{*}{ Release date } \\
\hline & & $N$ & Mean & SD & Range & Length type & \\
\hline \multirow[t]{4}{*}{2010} & Klamath River & 5 & 1.84 & 0.20 & $1.69-2.18$ & Total & May $10-11$ \\
\hline & Willapa Bay & 9 & 1.46 & 0.19 & $1.23-1.84$ & Fork & August 26 \\
\hline & Grays Harbor & 10 & 1.48 & 0.14 & $1.32-1.73$ & Fork & September 16 \\
\hline & Columbia River & 1 & $\mathrm{Na}$ & $\mathrm{Na}$ & $0.98-0.98$ & Fork & September 8 \\
\hline 2011 & Grays Harbor & 4 & 0.99 & 0.10 & $0.92-1.13$ & Fork & June 8-July 8 \\
\hline
\end{tabular}

\section{Coos Bay Estuary}

Number of Tagged Fish Detected

During the one year of study in Coos Bay from October 2009 through October 2010, we detected only one green sturgeon on the 20 receivers deployed from the bar at the mouth of the estuary to rkm 21.6. The fish had been tagged in the Klamath River and was detected for about 2 hours on July 12, 2010 at receiver stations one and two, which were closest to the mouth of Coos Bay at green buoy 5A. No other results will be presented for Coos Bay. 


\section{Lower Columbia River Estuary}

\section{Environmental Conditions}

Profiles of daily median water temperature differed between the lower (rkm 4.8) and the upper (rkm 38) parts of the estuary during some months of 2010 (fig. 3). Median water temperatures at both locations increased from about $11.0^{\circ} \mathrm{C}$ in early May to $16.0^{\circ} \mathrm{C}$ in late June, and then diverged. Median water temperatures in the upper part of the study area continued to increase, peaked in midAugust at $22.3^{\circ} \mathrm{C}$, and then decreased to about $13.0^{\circ} \mathrm{C}$ in early November. In contrast, median water temperatures in the lower estuary leveled off and became more variable, oscillating between 13.5 and $17.9^{\circ} \mathrm{C}$ from early July to mid-October, and then decreased to about $13^{\circ} \mathrm{C}$ in early November when water temperatures were again similar to the upper estuary. The maximum difference between the lower and the upper parts of the study area during mid-August was $6.4^{\circ} \mathrm{C}$.

Daily variation in water temperatures also differed between the lower and upper areas of the study area (fig. 3). Daily differences between minimum and maximum water temperatures in the upper part of the study area were less than $2^{\circ} \mathrm{C}$, whereas daily differences in the lower estuary ranged from 0.5 to $9.5^{\circ} \mathrm{C}$.
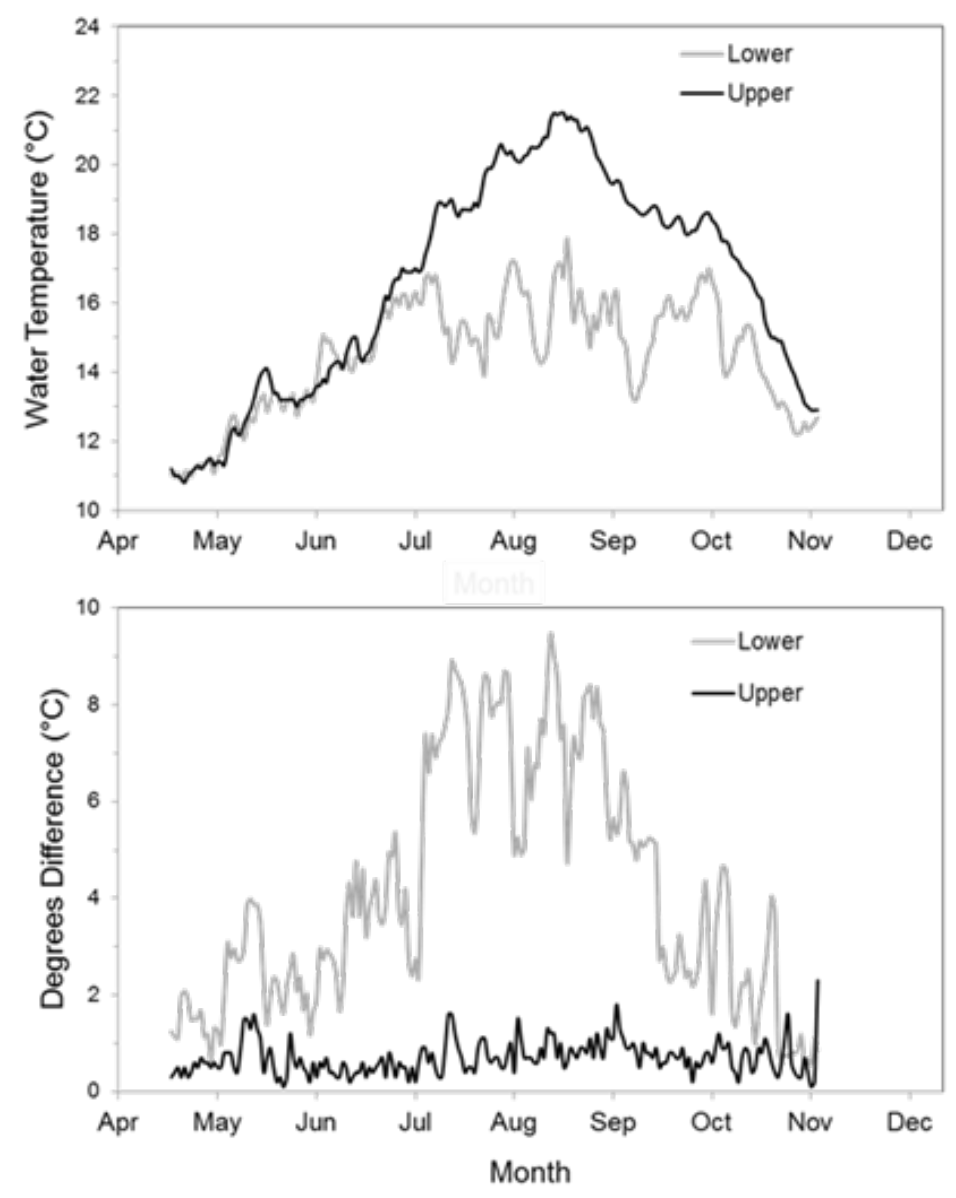

Figure 3. Profiles showing median hourly water temperatures (top) and difference between the maximum and minimum daily temperatures (bottom) in degrees Celsius $\left({ }^{\circ} \mathrm{C}\right.$ ) in the lower (river kilometer 4.8) and upper (river kilometer 38) parts of the study area, lower Columbia River Estuary, Washington and Oregon, 2010. 


\section{Number of Tagged Fish Detected}

Nine green sturgeon were detected in the acoustic detection array in 2010, and 10 fish were detected there in 2011 (table 2). Some receivers were lost in the detection array during both years and the dates on which each station was operating are provided in appendix A. Additionally, some receivers were moved or removed by commercial fishers during episodic salmon drift gill net fishery openings. During the 2 years, we detected 27.6 percent (8 of 29) of the fish released by the USGS. In 2010, four of the fish detected were tagged during the same year in June, September, and October by the USGS and its collaborators, or in independent studies - one in the lower Columbia River, two in Willapa Bay, and one in the Klamath River. The Bureau of Reclamation (Reclamation) and California Water Science Center released the remaining five fish in the Sacramento River prior to 2010. Three of the green sturgeon released in the Sacramento River were known Southern DPS fish. In total, seven of the nine fish (77.8 percent) detected were released in independent studies. Only 8 percent (2 of 25) of the fish released by the USGS were detected, and one of those fish had been released in the Columbia River Estuary. There were 1,777 total valid detections among all receivers. The total number of detections per fish ranged from 3 to 1,251 (median 19).

Table 2. Summary statistics for green sturgeon detected in the lower Columbia River Estuary, Washington and Oregon, 2010-11.

[CAWA, California Water Science Center; NMFS, National Marine Fisheries Service; Reclamation, Bureau of Reclamation; USGS, U.S. Geological Survey; YTRIB, Yurok Tribe Fishery Program; N, total number of detections]

\begin{tabular}{|c|c|c|c|c|c|c|c|}
\hline \multirow{2}{*}{ Year } & \multirow{2}{*}{ Tag owner } & \multirow{2}{*}{ Release site } & \multirow{2}{*}{$\begin{array}{l}\text { Release } \\
\text { date }\end{array}$} & \multicolumn{2}{|c|}{ Detection dates } & \multirow{2}{*}{$\begin{array}{l}\text { Residence } \\
\text { time (days) }\end{array}$} & \multirow{2}{*}{$N$} \\
\hline & & & & First & Last & & \\
\hline \multirow[t]{9}{*}{2010} & USGS & Columbia River & 09-08-2010 & 09-08-2010 & $10-20-2010$ & 41.881 & 159 \\
\hline & USGS & Willapa Bay & 08-26-2010 & 08-31-2010 & 09-02-2010 & 1.149 & 29 \\
\hline & NMFS & Willapa Bay & 08-26-2010 & $10-30-2010$ & $10-30-2010$ & 0.013 & 7 \\
\hline & YTRIB & Klamath River & 06-13-2010 & 08-15-2010 & 08-15-2010 & 0.005 & 6 \\
\hline & Reclamation & Sacramento River & 06-14-2006 & 09-10-2010 & 09-10-2010 & 0.103 & 19 \\
\hline & Reclamation & Sacramento River & 04-22-2009 & 05-21-2010 & $05-21-2010$ & 0.001 & 3 \\
\hline & CAWA & Sacramento River & 10-10-2009 & 06-24-2010 & 06-28-2010 & 4.242 & 286 \\
\hline & CAWA & Sacramento River & 10-19-2009 & 05-15-2010 & $10-02-2010$ & 139.756 & 1,251 \\
\hline & CAWA & Sacramento River & $\mathrm{Na}$ & 07-02-2010 & 07-10-2010 & 7.849 & 17 \\
\hline \multirow[t]{10}{*}{2011} & USGS & Willapa Bay & 08-26-2010 & 08-21-2011 & 08-22-2011 & 0.519 & 23 \\
\hline & USGS & Willapa Bay & 08-26-2010 & 06-13-2011 & 08-30-2011 & 77.308 & 1,881 \\
\hline & USGS & Grays Harbor & 09-16-2010 & 09-05-2011 & 09-06-2011 & 1.209 & 35 \\
\hline & USGS & Grays Harbor & 09-16-2010 & $10-10-2011$ & $10-15-2011$ & 3.160 & 38 \\
\hline & USGS & Grays Harbor & 09-16-2010 & 05-29-2011 & 05-29-2011 & 0.003 & 3 \\
\hline & USGS & Grays Harbor & 09-16-2010 & 07-20-2011 & 07-31-2011 & 10.334 & 100 \\
\hline & USGS & Grays Harbor & 07-07-2011 & $10-17-2011$ & $10-17-2011$ & 0.113 & 11 \\
\hline & NMFS & Willapa Bay & 08-26-2010 & 08-07-2011 & 08-07-2011 & 0.004 & 2 \\
\hline & NMFS & Willapa Bay & 08-26-2010 & 08-04-2011 & 08-04-2011 & 0.012 & 13 \\
\hline & Reclamation & Sacramento River & 07-11-2010 & 09-10-2011 & 09-11-2011 & 0.101 & 13 \\
\hline
\end{tabular}


In 2011, all but 1 of the 10 fish detected were released in 2010 or before. Seven of the 10 fish (70.0 percent) detected were released as part of the current study, two in Willapa Bay and five in Grays Harbor. Two of the remaining three fish were released by the NMFS in Willapa Bay and Reclamation released one fish in the Sacramento River. The fish tagged in 2011 was released on July 7 in Grays Harbor. We detected 24 percent (6 of 25) of the USGS fish released in 2010 and 25 percent (1 of 4) of the fish released in 2011. Two of the tagged fish released in Willapa Bay were detected during both years of the study. There were 2,119 total detections in 2011, and the number of detections per individual fish ranged from 2 to 1,881 (median, 23).

\section{Timing of Ingress and Egress, and Residence Time}

Tagged green sturgeon inhabited the detection array from May through October during both 2010 and 2011, but individual residence times were highly variable (table 2, fig. 4). In 2010, ingress dates based on the time of first detection in the array ranged from May 15 through October 30, but ingress times for the four fish captured in 2010 may have been influenced by the time of their release. The Klamath River fish was released on June 13, and the three fish captured and tagged in the Columbia River and Willapa Bay were released on August 26 or thereafter. The five Sacramento River fish released prior to 2010 entered the Columbia River from May through September, and their ingress and residence times would not be similarly affected. Egress dates also were not likely affected by the time of release and ranged from May 21 to October 30. The maximum number of tagged fish present in the estuary peaked in September $(N=4)$. Residence times in the estuary calculated from the first and last detection times in the detection array were highly variable, ranging from 0.001 to 139.756 days (table 2) (median, 1.149 days). Residence times for fish detected only in the lower $4.8 \mathrm{rkm}$ typically were short, ranging from 0.001 to 0.103 days (median, 0.009 days), whereas the residence times of fish detected farther upriver generally were longer, ranging from 1.703 to 139.756 days (median, 7.849 days).

In 2011, like in 2010, tagged green sturgeon entered and left the estuary during May through October. Unlike in 2010, in 2011, all but one of the fish detected were released the previous year or earlier. Thus, most of the ingress and residence times were not potentially affected by the time of release. The maximum number of tagged fish present in the estuary peaked in August $(N=4)$. Residence times ranged from 0.003 to 77.308 days (median, 0.316 days). Like in 2010, in 2011, the residence times of fish detected only in the lower $4.8 \mathrm{rkm}$ of the estuary were relatively short, ranging from 0.003 to 3.160 days (median, 0.107 days), whereas the two fish detected farther upriver had residences times of 10.334 and 77.308 days. 


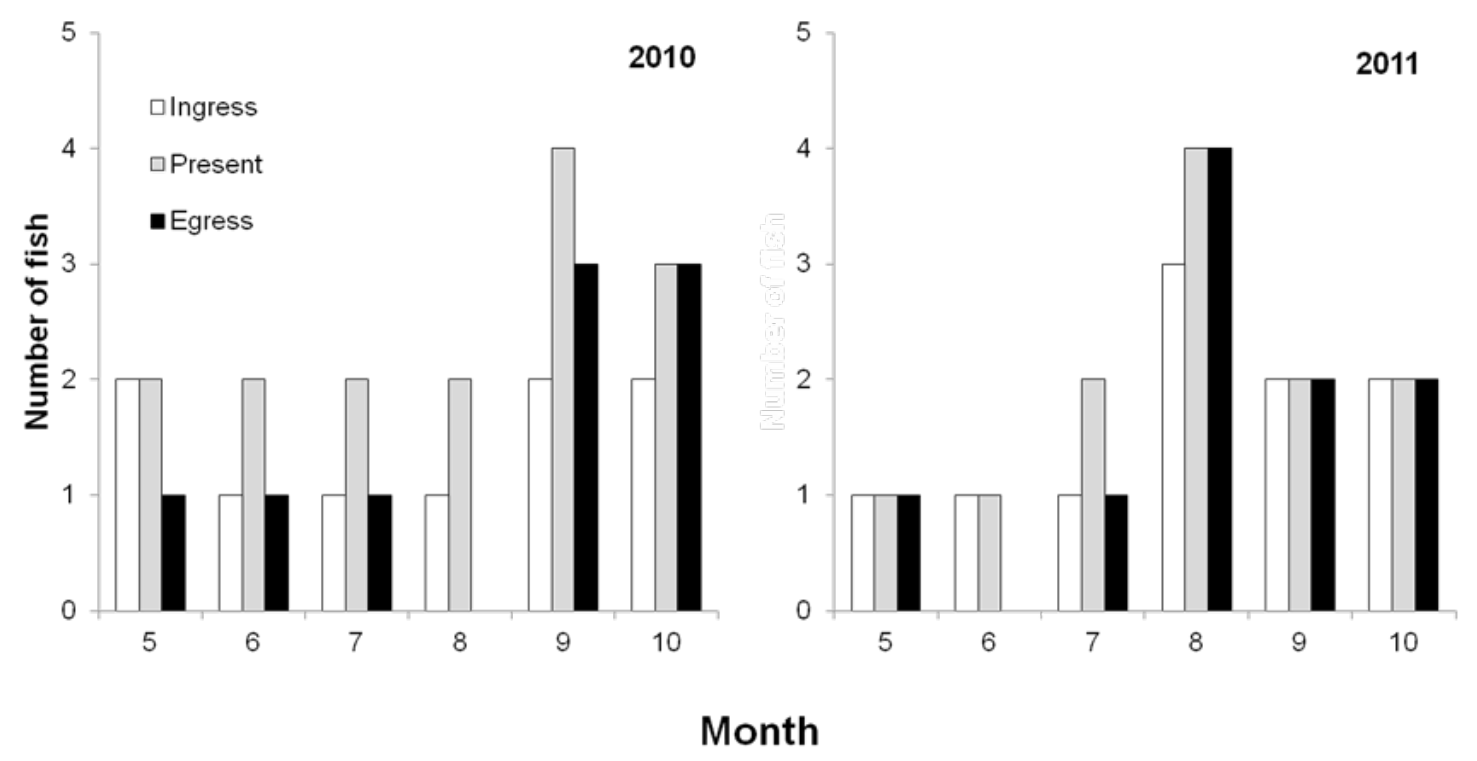

Figure 4. Graphs showing number of acoustic-tagged green sturgeon entering, leaving, and inhabiting the lower Columbia River Estuary by month, Washington and Oregon, 2010-11.

\section{Extent of Upstream Migration}

Acoustically tagged green sturgeon were detected at the uppermost receiver station (station 152; rkm 37.8) in 2010. This suggests that sturgeon may have moved farther upstream, but we were unable to determine to what extent sturgeon moved past this point. However, they were not detected at the receiver located at rkm 88 . The number of tagged green sturgeon detected upriver decreased rapidly with distance from the mouth of the estuary during both years. In 2010, four of the nine fish entering the estuary were never detected upriver of the entrance to the Ilwaco, Washington, channel at rkm 4.8, and only two fish were detected upriver of rkm 32.2 (fig. 5). The median distance green sturgeon migrated upriver in 2010 was $16.1 \mathrm{rkm}$.

In 2011, 8 of the 10 fish entering the estuary were never detected upriver of rkm 4.8. The relatively lower proportion of fish detected upriver of the Ilwaco Channel entrance in 2011 than in 2010 may have been owing to the reduced number of receivers deployed in $201 \mathrm{l}$ and receivers that were lost in season. No data were collected at stations 125 and 129 after June 2 and at station 131 after July 14. Stations 135 and 137 were lost early in the season and no usable data were collected. The two fish detected upriver of rkm 4.8 in 2011 migrated as far as rkm 32.2 and 34.4 (stations 142 and 145, respectively). 


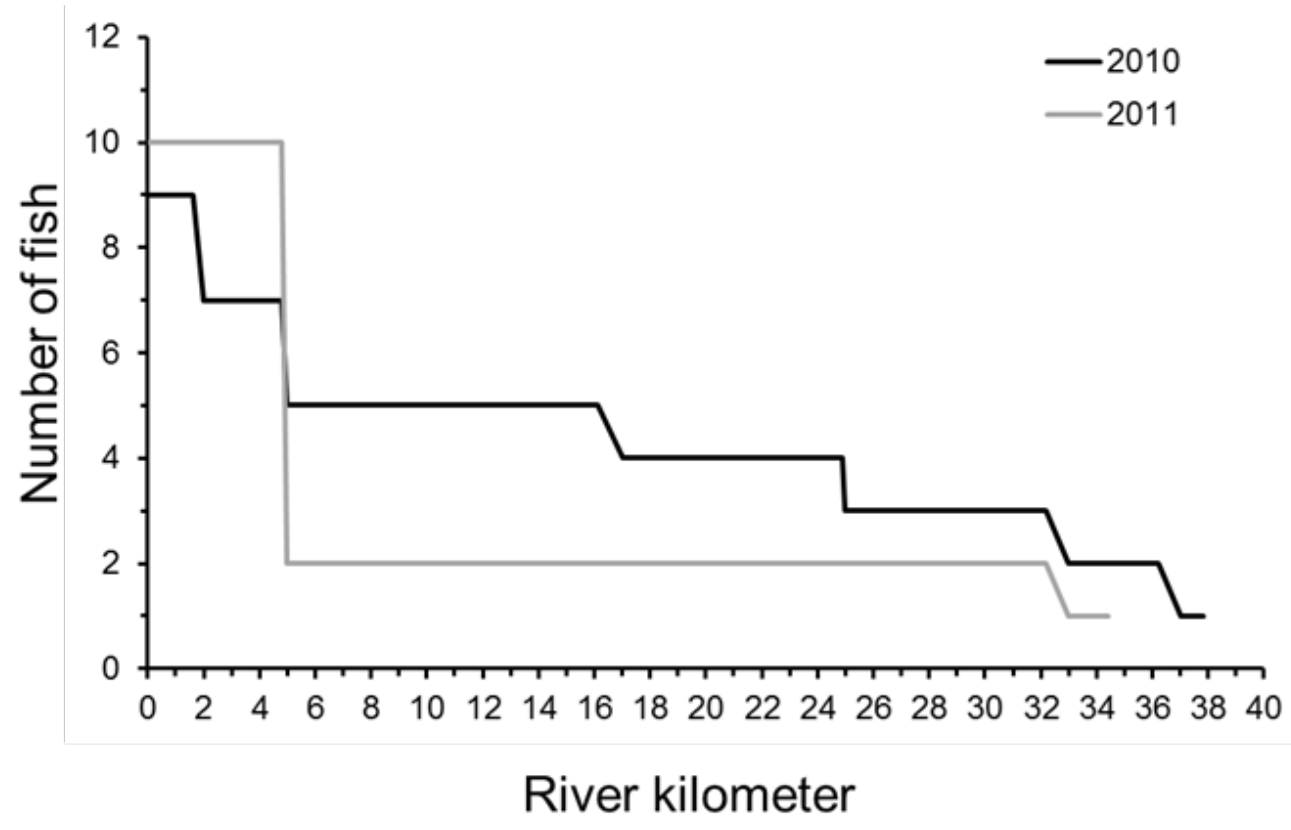

Figure 5. Graph showing extent of upriver migration by acoustic-tagged green sturgeon in the lower Columbia River Estuary, Washington and Oregon, 2010-11.

\section{Spatial Distribution of Fish}

Green sturgeon were widely, but not uniformly, distributed among stations in the lower $38 \mathrm{rkm}$ of the estuary. In 2010, 74.2 percent of the receivers (23 of 31) detected fish, and the number of fish detected per receiver ranged from zero to six (fig. 6). Generally, the greatest numbers of fish were detected in the northern part the estuary at the Ilwaco Channel, in the unmaintained North Channel east and west of Point Ellice, and in the shallow shoals near Taylor Sands. Stations near the South Channel from Clatsop Spit to the eastern side of Tongue Point (141) detected fewer fish. Station 128 in the North Channel was not operational after May 27, and stations 133, 134, and 141 near the South Channel were not operational after July 20 (fig. A1). Thus, the number of tagged fish detected at these stations could be biased low.

The station at the entrance to the Ilwaco Channel (150) was the only station to detect the maximum of six fish, followed by the stations in the North Channel between Chinook and Grays Point (stations 124, 126, 135), at Taylor Sands (station 137), and outside the north anchorage at Astoria (station 138), which detected three to four fish each. The remaining 16 stations detected two or less fish. Seven stations-in or near Baker Bay (station 151), Youngs Bay (stations 127,129, 130, and 132), Cathlamet Bay (station 145), and Grays Bay (station 143) — detected no fish. 


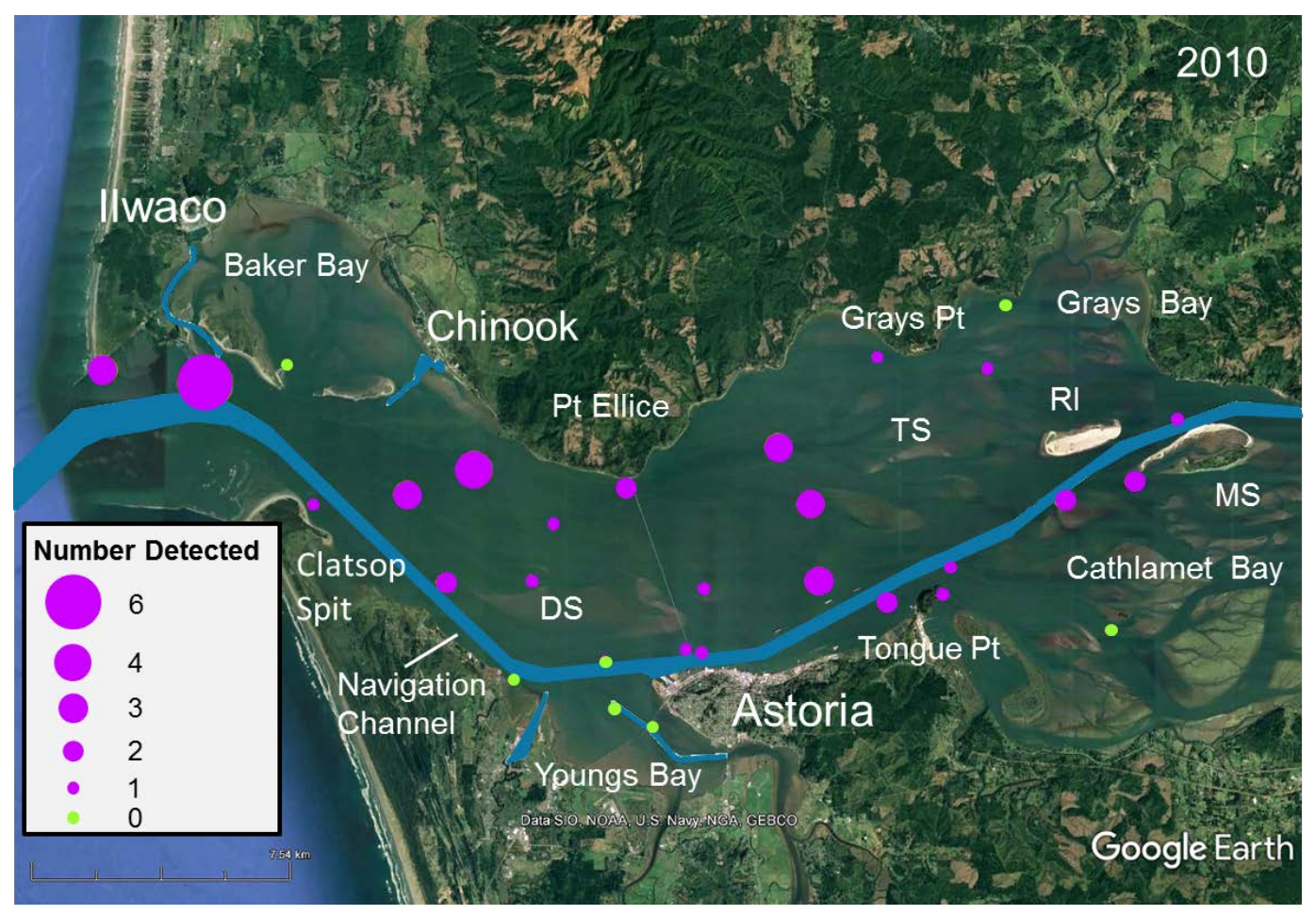

Figure 6. Image showing number of individual acoustic-tagged green sturgeon detected at receiver stations in the lower Columbia River Estuary, Washington and Oregon, 2010. The southern navigation channel and smaller auxiliary channels are shown with solid blue lines. DS, Desdemona Sands; Pt, Point; TS, Taylor Sands; RI, Rice Island; MS, Miller Sands. Image source: Google Earth ${ }^{\mathrm{TM}}$, Scripps Institution of Oceanography, National Oceanic and Atmospheric Administration, U.S. Navy, National Geospatial-Intelligence Agency, General Bathymetric Chart of the Oceans.

The distribution of tagged sturgeon among estuary areas in the reduced 14-receiver detection array in 2011 was concentrated near the mouth of the river (fig. 7). Numbers of fish detected at stations near the South Channel at green buoy 25 southeast of Clatsop Spit (station 125) and near Youngs Bay (station 129), and in the North Channel at Point Ellice (station 131) were all potentially biased low because they were not operational for much of the season (fig. A2). Stations 135 and 137 were lost early in the season and no usable data were collected. All 10 fish entering the estuary were detected at the Ilwaco Channel entrance, but only two fish were detected farther upriver. The station in the North Channel southeast of Chinook (station 126), the station east of Desdemona Sands (station 149), and the station outside the north anchorage at Astoria (station 138) each detected both fish, and the remaining stations each detected one fish. Stations near the main channel at Youngs Bay (station 129) and Miller Sands (station 146) detected neither of the two fish. 


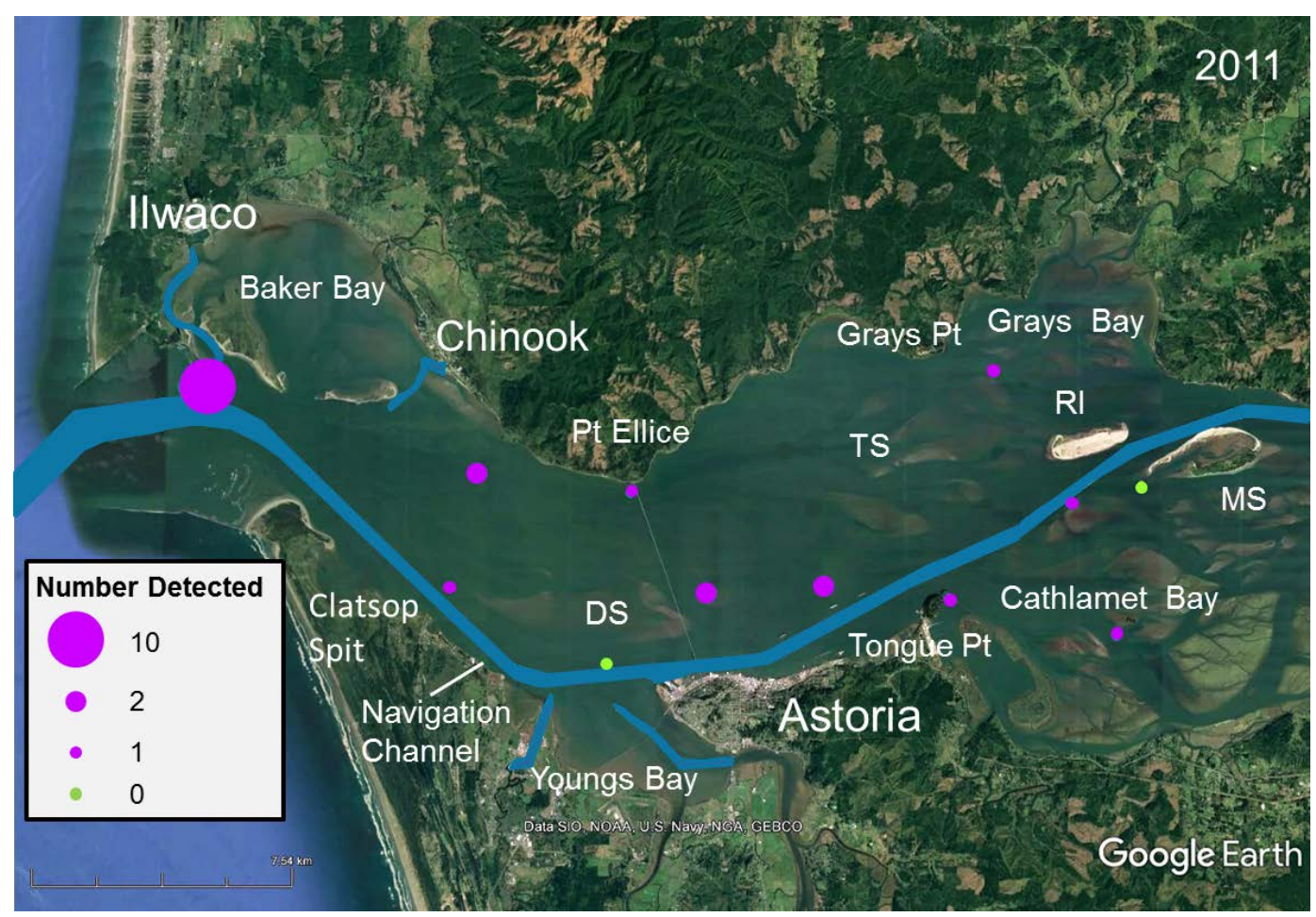

Figure 7. Image showing number of individual acoustic-tagged green sturgeon detected at receiver stations in the lower Columbia River Estuary, Washington and Oregon, 2011. The southern navigation channel and smaller auxiliary channels are shown with solid blue lines. DS, Desdemona Sands; Pt, Point; TS, Taylor Sands; RI, Rice Island; MS, Miller Sands. Image source: Google Earth ${ }^{\mathrm{TM}}$, Scripps Institution of Oceanography, National Oceanic and Atmospheric Administration, U.S. Navy, National Geospatial-Intelligence Agency, General Bathymetric Chart of the Oceans.

\section{Intensity of Use}

The intensity of use, measured as the number of fish detections at each station, generally was greatest from Point Ellice to Rice Island (fig. 8). In 2010, the total number of detections per receiver ranged from 0 to 259. Stations with moderately high-to-high numbers of detections $(>83)$ included the shallow shoals between the Desdemona and Taylor Sands (stations 137, 138, 149), the northern channel near Point Ellice (station 131) and north of Taylor Sands (station 135), and near the South Channel at Astoria (station 134), Tongue Point (station 141), and Rice Island (station 144). Almost all stations downriver of Point Ellice (station 131) had relatively low numbers of detections $(<44)$ regardless of the estuary area. The only exception was the station at the entrance to the Ilwaco Channel, which had 70 detections. Station 128 in the North Channel was not operational after May 27, and stations 133, 134, and 141 near the South Channel were not operational after July 20 (fig. A1), so numbers of detections may be biased low at these sites.

In 2011, the stations with greatest number of detections generally were located upriver from Point Ellice, as in 2010, and at the Ilwaco Channel (station 150, fig. 9). The upriver stations with the greatest number of detections included the shallow shoal area outside the north anchorage at Astoria (station 138), Cathlamet Bay (station 145), the South Channel near Tongue Point (station 140), and the North Channel near Grays Bay (station 142). The numbers of detections at stations 125, 129, and 131 were all potentially biased low because they were not operational for much of the season (fig. A2). 


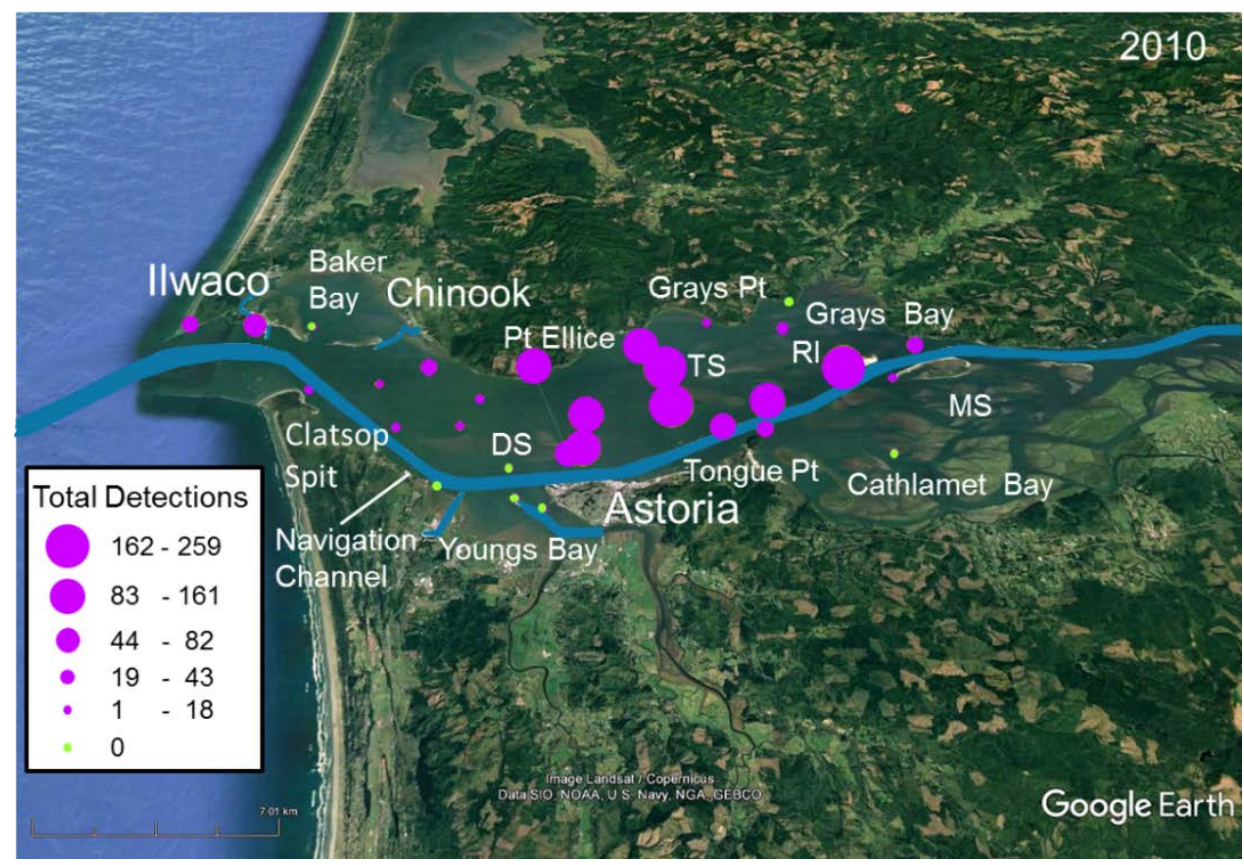

Figure 8. Image showing number of acoustic-tagged green sturgeon detections at receiver stations in the lower Columbia River Estuary, Washington and Oregon, 2010. The southern navigation channel and smaller auxiliary channels are shown with solid blue lines. DS, Desdemona Sands; Pt, Point; TS, Taylor Sands; RI, Rice Island; MS, Miller Sands. Image source: Google Earth ${ }^{\mathrm{TM}}$, Scripps Institution of Oceanography, National Oceanic and Atmospheric Administration, U.S. Navy, National Geospatial-Intelligence Agency, General Bathymetric Chart of the Oceans.

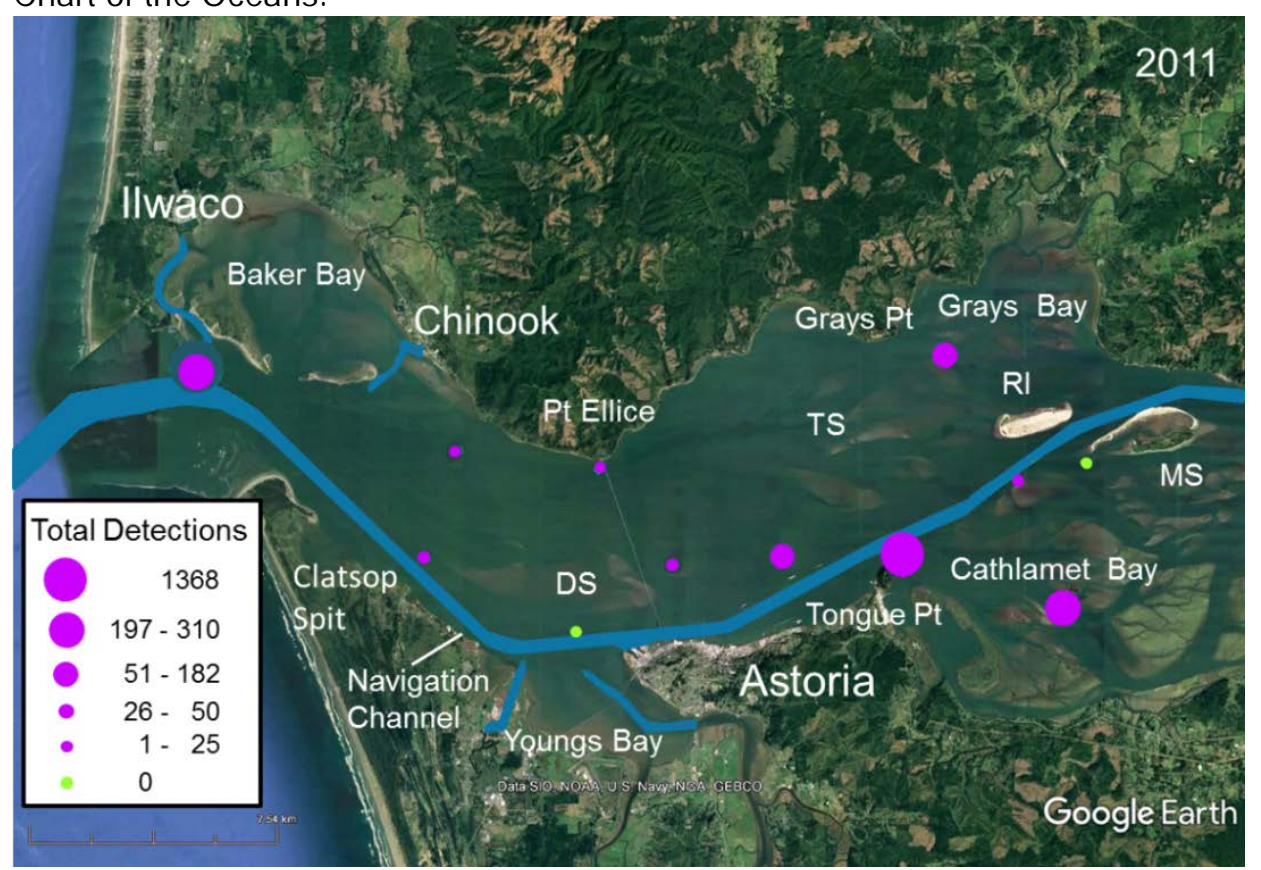

Figure 9. Image showing number of acoustic-tagged green sturgeon detections at receiver stations in the lower Columbia River Estuary, Washington and Oregon, 2011. The southern navigation channel and smaller auxiliary channels are shown with blue lines. DS, Desdemona Sands; Pt, Point; TS, Taylor Sands; RI, Rice Island; MS, Miller Sands. Image source: Google Earth ${ }^{\mathrm{TM}}$, Scripps Institution of Oceanography, National Oceanic and Atmospheric Administration, U.S. Navy, National Geospatial-Intelligence Agency, General Bathymetric Chart of the Oceans. 


\section{Fish Depths and Water Temperatures}

Fish depths obtained from the detections of tags equipped with pressure sensors indicated that the green sturgeon used the deeper South and North channel habitats (bottom depth $\geq 10 \mathrm{~m}$ ), as well as, the more shallow (bottom depth $<10 \mathrm{~m}$ ) sandy shoal, shoreline, and bay habitats. Green sturgeon use of the deep and shallow habitats within a 600-m radius of each receiver station was dependent on individual fish behavior and differences in the local bathymetry among stations. Temperatures experienced by green sturgeon in the channel and non-channel habitats varied widely, spatially and temporally, among stations.

In 2010, only two green sturgeon were detected with transmitters that had a pressure sensor, and the distributions of their depths differed markedly (figs. 10 and 11). Almost all detections of fish No. 2635 were associated with the shallow depths outside the deeper channel habitat. The five stations where it was detected included Lower Desdemona Sands (station 124), green buoy 25 southeast of Clatsop Spit (station 125), Taylor Sands (station 137), Grays Point (station 139), and the North Channel near Grays Bay (station 142). Median fish depths at these sites ranged from 3.4 to $5.4 \mathrm{~m}$ bws, and the single detection at station 124 was at a depth about $10 \mathrm{~m}$ bws. Overall, only 4 percent of the total detections $(N=25$ ) were in the channel habitats (bottom depth $\geq 10 \mathrm{~m}$ ), and 96 percent were in the shallow habitats (bottom depth $<10 \mathrm{~m}$ ). The minimum and maximum depths recorded were 2.7 and $10.0 \mathrm{~m}$ bws.

Water temperatures at fish depth obtained from the transmitter temperature sensor during August 31-September 2 differed by more than $5^{\circ} \mathrm{C}$ between downriver and upriver stations (fig. 10). Median temperatures ranged from 12.0 to $13.0^{\circ} \mathrm{C}$ in the North Channel near Lower Desdemona Sands (station 124) and green buoy 25 southeast of Clatsop Spit (station 125), whereas median temperatures ranged from 17.4 to $17.9^{\circ} \mathrm{C}$ at Taylor Sands (station 137), Grays Point (station 139), and the North Channel near Grays Bay (station 142). No water temperatures were recorded at station 126 . The minimum and maximum water temperatures during this period were 12.0 and $18.2^{\circ} \mathrm{C}$.

In contrast, fish No. 2661 was inhabiting both channel and non-channel habitats, in varying proportions, depending on the station location (fig. 11). There were only detections in the channel habitat in the main navigation channel at the mouth of the river at the North Jetty (station 121), the Ilwaco Channel entrance (station 150), Clatsop Spit (station 122), near green buoy 25 southeast of Clatsop Spit (station 125), and the North Channel at Point Ellice (station 131). Median fish depths at these five stations ranged from 11.0 to $22.2 \mathrm{~m}$. Fish detections were nearly equally distributed between the channel and non-channel habitats in the North Channel west and east of Point Ellice (stations 126 and 135), where median fish depths were 8.7 and $10.0 \mathrm{~m}$, respectively. Fish depths were associated only with shallow non-channel habitats at the stations west of Tongue Point (station 136), outside the north anchorage near Astoria (station 138), Rice Island (station 144), and Miller Sands (station 146). Median fish depths at these four stations ranged from 2.5 to $6.2 \mathrm{~m}$ bws. Overall, 64.0 percent of the total detections $(N=159)$ were in the navigation channel and 36.0 percent were outside the navigation channel. The transmitter was not equipped with a temperature sensor. 

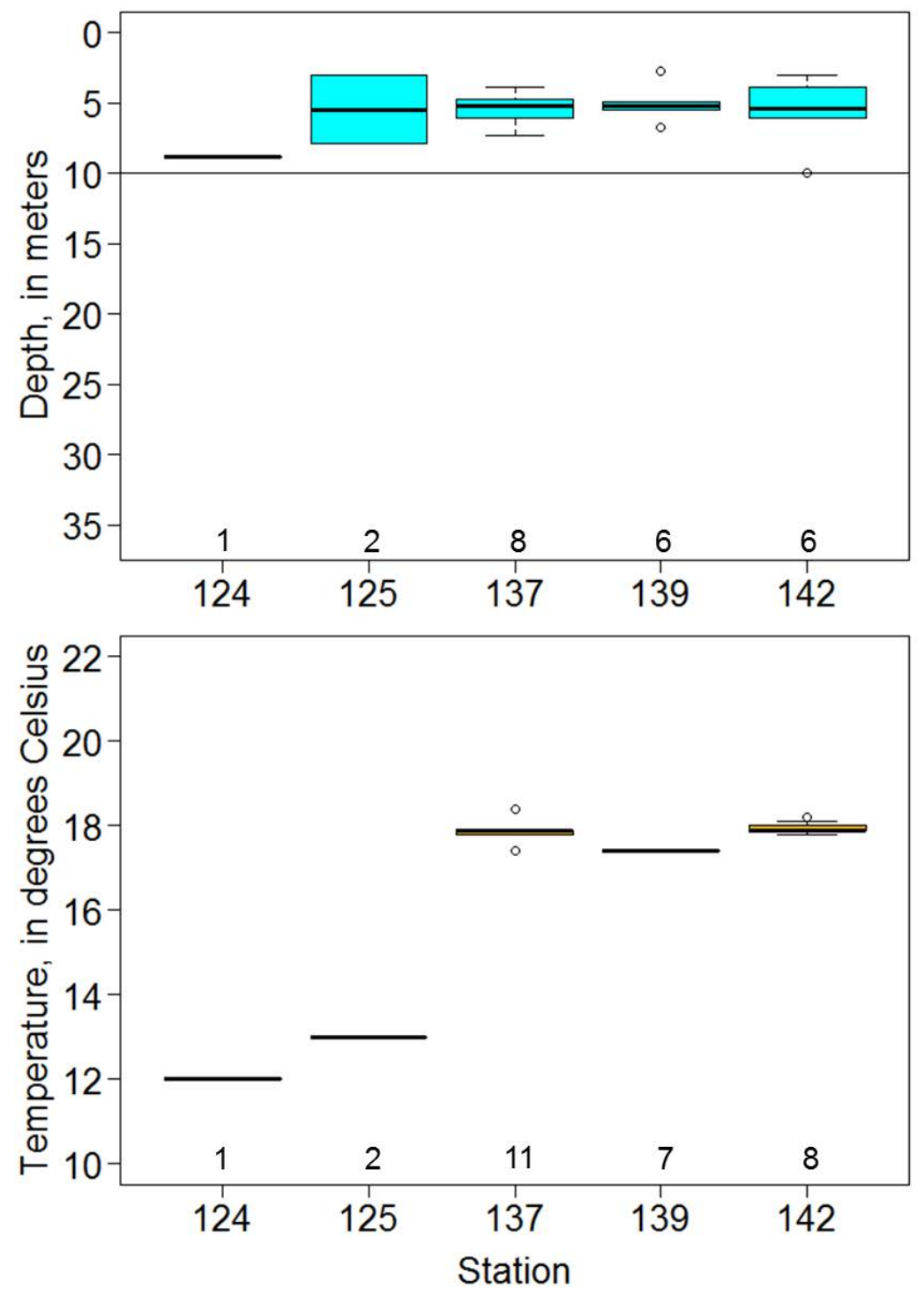

Figure 10. Boxplots showing fish depths below the water surface (top) and water temperatures (bottom) inhabited by fish No. 2635 in the lower Columbia River Estuary, Washington and Oregon, August 31-September 2, 2010. Sample sizes are shown above station Nos. Boxes range from the 25th to 75th percentiles (interquartile range) with a line indicating the median, whiskers represent the minimum and maximum values no more or less than 1.5 times the interquartile range, and empty circles represent suspected outliers less or greater than the minimum and maximum values. 


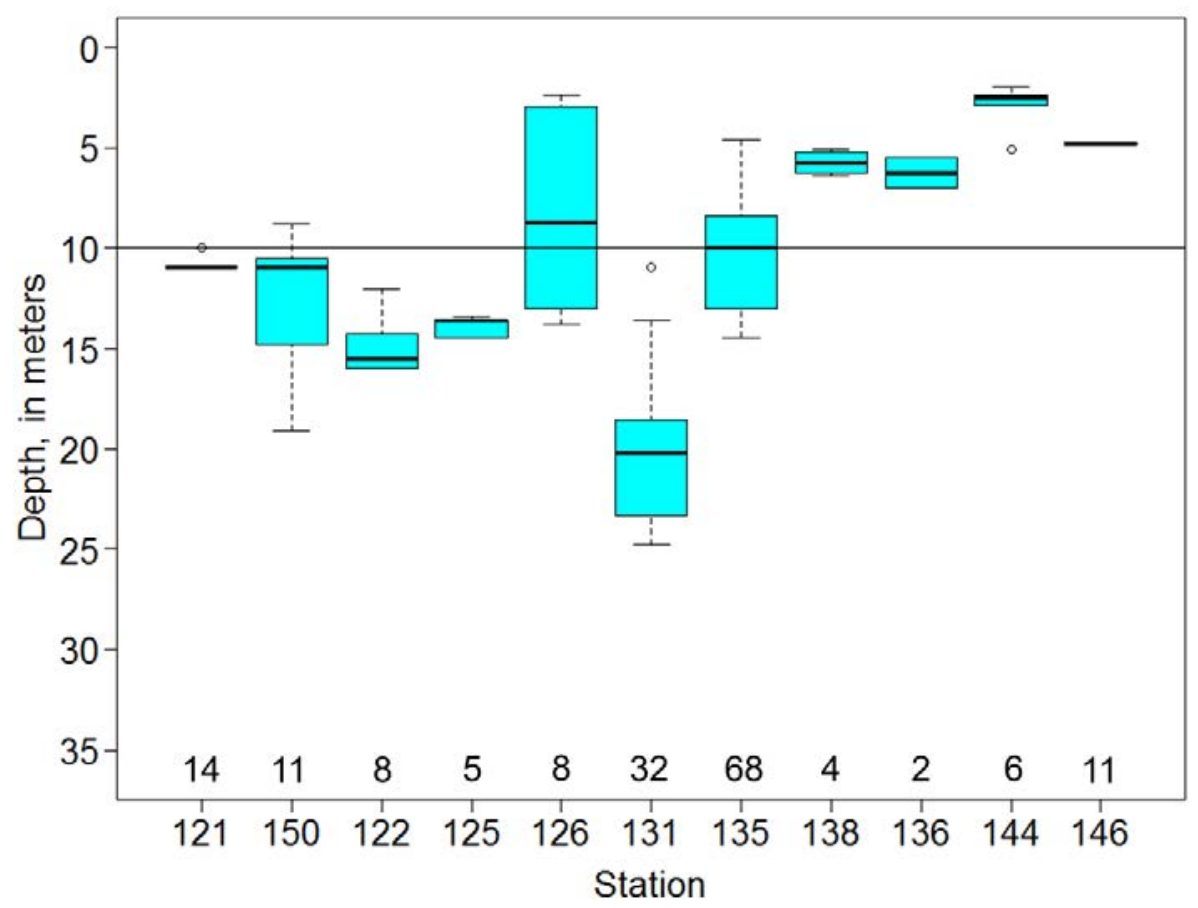

Figure 11. Boxplots showing fish depths below the water surface inhabited by fish No. 2661 in the lower Columbia River Estuary, Washington and Oregon, September 8-October 10, 2010. Sample sizes are shown above station Nos. Boxes range from the 25th to 75th percentiles (interquartile range) with a line indicating the median, whiskers represent the minimum and maximum values no more or less than 1.5 times the interquartile range, and empty circles represent suspected outliers less or greater than the minimum and maximum values.

In 2011, the results generally were similar to those in 2010. Six green sturgeon were detected with pressure sensitive tags, but four of the fish had detections only at the Ilwaco Channel entrance. One of the fish that was identified upriver, fish No. 2635, also was detected in 2010. The depths of fish No. 2635 were associated predominantly with shallow non-channel habitats at five of the eight stations where it was detected (fig. 12). This included the area near the main shipping channel at Rice Island (station 144), the North Channel station west of Point Ellice (station 126), and the stations at Desdemona Sands (station 149), outside the north anchorage near Astoria (station 138), and Cathlamet Bay (station 145). The median depths at these five stations ranged from 5.6 to $7.6 \mathrm{~m}$ bws. Fish No. 2635 was associated predominantly with deeper channel habitats in the main shipping channel at the Ilwaco Channel entrance (station 150) and Tongue Point (station 140), and in the North Channel near Point Ellice (station 131). About 60.0 percent of the detections at both Point Ellice and Tongue Point, and 79.0 percent of the detections at the Ilwaco Channel entrance were in the deeper channel habitat. Conversely, about 40.0 percent of detections at Point Ellice and Tongue Point, and 21.0 percent of the detections at the Ilwaco Channel entrance were associated with shallow habitats. Median fish depths at these three sites ranged from 10.4 to $14.2 \mathrm{~m}$ bws. Overall, about 46 percent of the total detections $(N=$ 1,940 ) were in the deeper channel habitat and 54 percent were in the shallow habitats. 

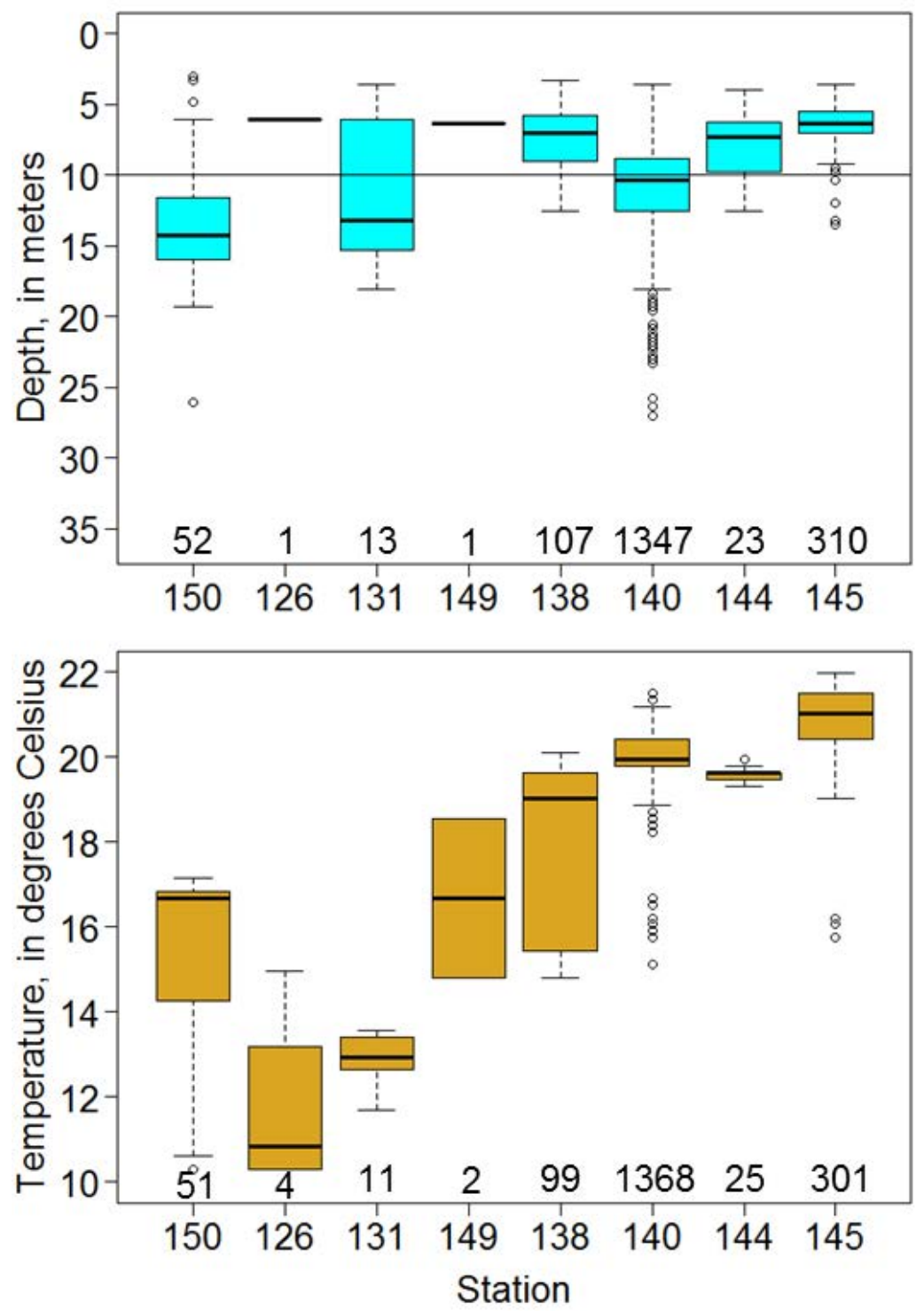

Figure 12. Boxplots showing fish depths below the water surface (top) and water temperatures (bottom) inhabited by fish number 2635 in the lower Columbia River Estuary, Washington and Oregon, June 13-August 30, 2011. Sample sizes are shown above station Nos. Boxes range from the 25th to 75 th percentiles (interquartile range) with a line indicating the median, whiskers represent the minimum and maximum values no more or less than 1.5 times the interquartile range, and empty circles represent suspected outliers less or greater than the minimum and maximum values.

Water temperatures inhabited by fish No. 2635 from June 13 through August 30 varied greatly among stations (fig. 12). A minimum temperature of $9.1^{\circ} \mathrm{C}$ was recorded at the entrance to the Ilwaco Channel (station 150) in the channel habitat and a maximum temperature of $22.0^{\circ} \mathrm{C}$ was recorded in non-channel habitat in Cathlamet Bay (station 145). Median temperatures generally were higher upriver of Point Ellice, ranging from 19.0 to $21.0^{\circ} \mathrm{C}$, at stations outside the north anchorage at Astoria (station 138), Tongue Point (station 140), Rice Island (station 144), and Cathlamet Bay (station 145). Median temperatures for stations east and west of Point Ellice (station 131) in the North Channel, and at the Ilwaco Channel entrance (station 150) ranged from 10.8 to $16.7^{\circ} \mathrm{C}$. 
Fish No. 2656 had detections predominantly in shallow non-channel habitats (fig. 13). This included stations in the North Channel west of Point Ellice (station 126) and near Grays Bay (station 142), and the stations outside the north anchorage near Astoria (station 138) and east of Desdemona Sands (station 149). Median fish depths ranged from 5.5 to $7.3 \mathrm{~m}$ bws. In the South Channel habitat at the Ilwaco Channel entrance (station 150), the median fish depth was $35.6 \mathrm{~m}$ bws. Overall, 11 percent of the total detections $(N=98)$ were in the channel habitat and 89 percent were in shallow non-channel areas. Median water temperatures associated with the non-channel habitats from July 20 through July 31 ranged from 17.5 to $19.1^{\circ} \mathrm{C}$, whereas the median temperature in the channel habitat at the Ilwaco Channel entrance (station 150 ) was $11.4^{\circ} \mathrm{C}$.
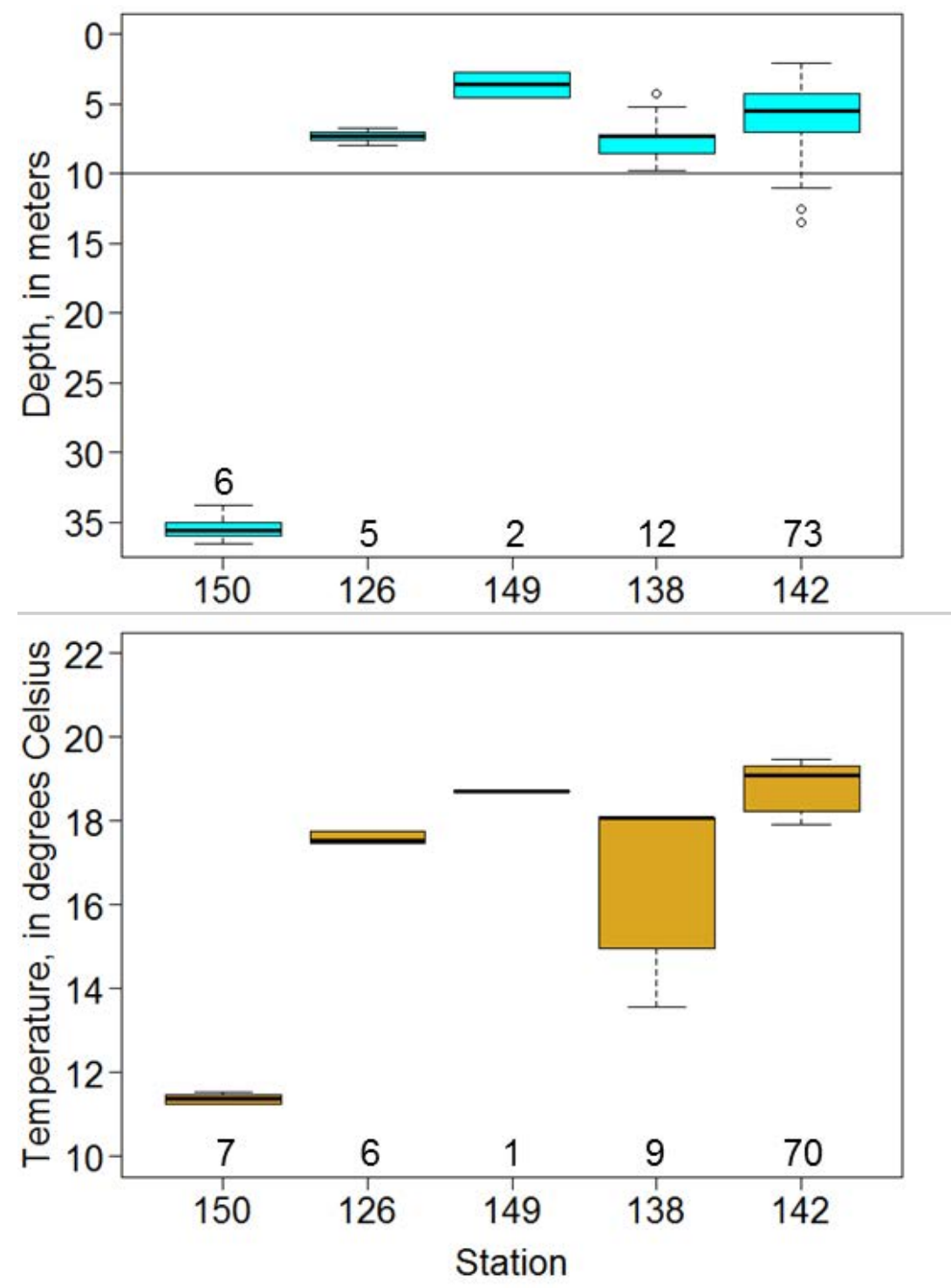

Figure 13. Boxplots showing fish depths below the water surface (top) and water temperatures inhabited by fish No. 2656 in the lower Columbia River Estuary, Washington and Oregon, July 20-July 31, 2011. Sample sizes are shown above station Nos. Boxes range from the 25th to 75th percentiles (interquartile range) with a line indicating the median, whiskers represent the minimum and maximum values no more or less than 1.5 times the interquartile range, and empty circles represent suspected outliers less or greater than the minimum and maximum values. 
Three of the four fish detected only at the Ilwaco Channel entrance in 2011 had detections only in channel habitats, and one of the fish had detections predominantly outside the channel (fig. 14). In the channel habitat, median fish depths ranged from 11.6 to $28.2 \mathrm{~m}$ bws, and in the shallow habitat, the median depth was $7.3 \mathrm{~m}$ bws. Median water temperatures at various depths and dates for these four fish ranged from 12.3 to $18.4^{\circ} \mathrm{C}$.
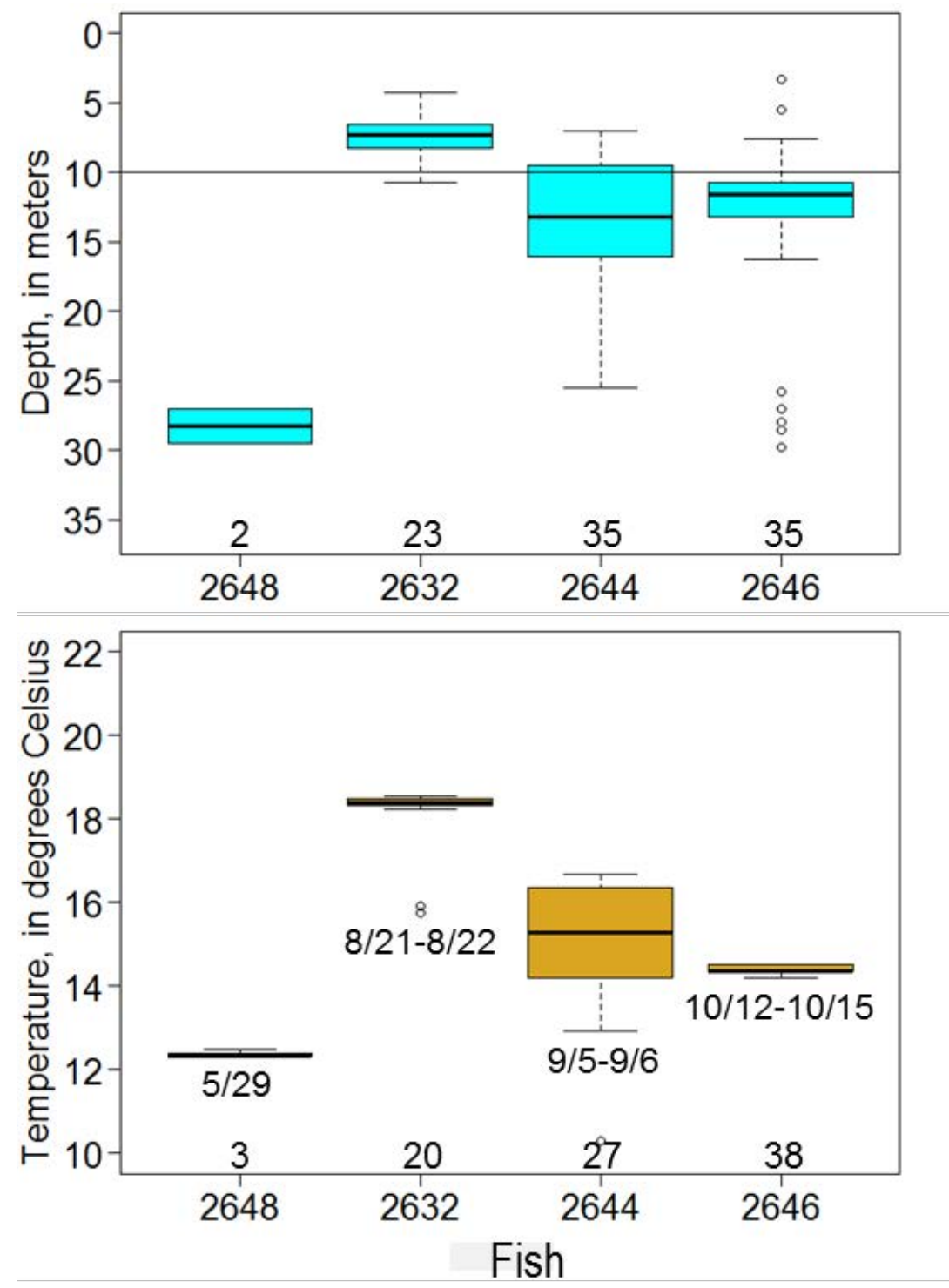

Figure 14. Boxplots showing fish depths below the water surface (top) and water temperatures inhabited by fish Nos. 2648, 2632, 2644, and 2646 at station 150 in the lower Columbia River Estuary, Washington and Oregon, 2011. Dates of the detections and sample sizes are shown above fish Nos. Boxes range from the 25th to 75th percentiles (interquartile range) with a line indicating the median, whiskers represent the minimum and maximum values no more or less than 1.5 times the interquartile range, and empty circles represent suspected outliers less or greater than the minimum and maximum values. 


\section{Discussion}

This report describes 1 year of acoustic-tagged green sturgeon detections in Coos Bay Estuary (rkm 0.0-21.6) and 2 years of detections in the lower Columbia River Estuary (rkm 0.0-38.0). Both study areas are part of the Southern DPS critical habitat under the ESA guidelines (National Oceanic and Atmospheric Administration, 2009, 74 FR 5300). The study was funded for only 1 year from October 2009 to October 2010, but collaboration with the NMFS conducting research in the Columbia River Estuary in 2011 allowed for a second year of data to be collected. The interpretation of the results of this study must be tempered by the fact that the sample sizes are small and, therefore, the conclusions drawn must be approached with a degree of caution and uncertainty. That said, given the lack of information concerning the variability of individual green sturgeon behavior in the lower Columbia River Estuary and other non-natal estuaries in general, this study can help inform managers and guide future studies. These results also corroborate some previously reported findings by other researchers.

The number of tagged fish detected during this study was low. During the 1 year of study in Coos Bay, we detected only one green sturgeon near the estuary mouth for about 2 hours. Lindley and others (2011) also reported only detecting a few acoustic-tagged green sturgeon in Coos Bay in 2005 and 2006. In the lower Columbia River Estuary, we detected 9 and 10 green sturgeon in 2010 and 2011, respectively. During those 2 years, we detected 33.0 percent of the Willapa Bay fish, 28.6 percent of the Grays Harbor fish, and 0.0 percent of the Klamath River fish released as part of this study. Overall, in 2011, we detected 24.0 percent of the fish that were released in 2010. Moser and Lindley (2007) reported that they detected about 43 percent (13 of 30) of the fish they released in Willapa Bay during 2003 in 2004.

Green sturgeon released by independent researchers using compatible technologies contributed greatly to this study. About 77.8 and 30.0 percent of the fish detected in 2010 and 2011, respectively, were acoustic-tagged fish released in Willapa Bay, and the Klamath and Sacramento Rivers during independent studies. Over one-half of the green sturgeon detected in 2010 had been released in the Sacramento River in previous years and three of the fish were known to be of Southern DPS origin. Other studies have reported that the Southern DPS usually constitutes most of the green sturgeon in the Columbia River Estuary (Israel and others, 2009; Lindley and others, 2011; Schreier and others, 2016), but there is some evidence the Northern DPS may constitute the greater proportion of the two DPSs in some years (Lindley and others, 2011). In 2011, only one of the fish that we detected had been released in the Sacramento River.

Green sturgeon were first detected in the estuary during May of both years, and fish continued to enter the estuary throughout summer and early autumn. The number of tagged fish in the estuary peaked during September in 2010 and August in 2011, and the last fish detections were in late October of both years. These findings are comparable to those of Lindley and others (2011), who reported that the number of green sturgeon in the lower Columbia River Estuary in 2005 and 2006 peaked in summer, that the earliest detections were in April and May, and that the latest detections were in September. Similarly, in Willapa Bay, about 50 km north of the Columbia River Estuary, green sturgeon were first detected in early May and last detected in early November during 2004 (Moser and Lindley, 2007). 
Green sturgeon detected only as far from the mouth of the estuary as the Ilwaco Channel entrance (rkm 4.8) during the 2 years remained within the acoustic array only briefly, with median residence time of 0.057 days (range $0.001-3.160$ days, $N=12$ ). These fish may have remained near the estuary mouth for a longer period undetected, since there were at most two stations in this area, or they may have left the estuary entirely. Fish detected upriver of the Ilwaco Channel entrance had a median residence time of 10.334 days (range 1.703-139.756 days, $N=7$ ). However, the two fish with the longest residence times (77.308 and 139.756 days) had gaps of 40 to 131 days in their detection histories and likely left the estuary for a time and later returned, or moved farther upriver above the acoustic detection array. Moser and Lindley (2007) noted that tagged green sturgeon released in Willapa Bay made rapid intra- and inter-estuary movements, either of which might explain the short residence times near the mouth of the estuary and the long time gaps in some of the fish-detection histories. During their study, tagged fish traveled from Willapa Bay to the Columbia River Estuary in as few as 5 days.

One of the tagged green sturgeon moved up the estuary to at least $37.8 \mathrm{rkm}$ where our mostupstream receiver in the lower estuary was located, but overall, the number of fish migrating upriver decreased rapidly with the distance traveled from the estuary mouth. No fish were detected at the two receiver stations farther upriver at rkm 88 in 2010 and rkm 116 in 2011, where two additional receivers were deployed. Schreier and others (2016) recently reported evidence of age-0 green sturgeon at the freshwater interface in the Columbia River. About 44.4 percent of the fish in 2010 and 80.0 percent of the fish in 2011 were never detected upriver of the Ilwaco, Washington, channel entrance at rkm 4.8. About 36.8 percent of the fish entering the estuary were detected as far upriver as rkm 16, and 26.3 percent were detected upriver of rkm 32. The lower percentage of fish detected migrating upriver of the Ilwaco Channel entrance in 2011 may have been owing to the reduced number of receivers deployed that year and receivers that were lost prior to the end of the field season.

The greatest numbers of green sturgeon were detected near the mouth of the river at the Ilwaco Channel entrance (rkm 4.8), and lesser numbers of fish were detected at the upriver sites. This suggests that green sturgeon may be using the mouth of the Columbia River as a stopover in route to Willapa Bay or Grays Harbor if they are not moving upstream to spawn (Schreier and others, 2016). Among the stations upriver of the Ilwaco Channel, the numbers of fish were higher at the receiver stations in the unmaintained North Channel and shallow sand shoals near Desdemona and Taylor sands than in areas adjacent to the main shipping channel along the south edge of the estuary. One of the stations in the North Channel and three stations adjacent to the South Channel were not present much of the season in 2010, however, and the numbers of fish using these sites may have been biased low. The only stations where green sturgeon were not detected during the study were at the receivers in Baker and Youngs Bays. Three acoustic-tagged green sturgeon were detected during a study in Baker Bay during September-November 2008 (Parsley, 2009). Only one receiver was deployed in Baker Bay during the current study in 2010, and green sturgeon could easily have been present in areas outside its range of coverage. No receivers were deployed in Baker Bay in 2011.

The intensity of use tended to be highest from Point Ellice (rkm 20.1) to Rice Island (rkm 33.0). There were relatively high numbers of detections in the shallow shoals between Desdemona and Taylor sands; the North Channel near Point Ellice; the South Channel near Astoria, Tongue Point, and Rice Island; and in Cathlamet Bay. With the exception of the site at the Ilwaco Channel entrance, the stations downriver of Point Ellice had relatively low numbers of detections. 
The use of channel and non-channel habitats varied among estuary areas and among individuals. Two green sturgeon detected in 2010 and six fish detected in 2011 had transmitters equipped with pressure sensors and were detected at fish depths ranging from 2.0 to $36.5 \mathrm{~m}$ bws. Four of these fish were detected only at the Ilwaco Channel (rkm 4.8) and were detected predominantly at fish depths greater than or equal to $10 \mathrm{~m}$. The other four fish were detected upriver of the Ilwaco Channel entrance. Two of these fish were associated predominantly with shallow habitats, whereas the other two fish occupied a mixture of channel and non-channel habitats. Overall, the percentage of detections in the shallow habitat for these four fish ranged from 36 to 96 percent, and the percentage of detections in the channel habitat ranged from 4 to 64 percent. Green sturgeon were detected predominantly in channel habitat at the stations near the estuary mouth at the North Jetty, entrance to the Ilwaco Channel, Clatsop Spit, and Point Ellice at median fish depths ranging from 11.0 to $35.6 \mathrm{~m}$. Fish used both channel and non-channel habitats near the South and North channels south of Chinook. East of Point Ellice to Miller Sands, fish typically were only detected in shallow non-channel habitats with median depths ranging from 2.5 to $7.3 \mathrm{~m}$. The only exceptions to this were the stations at Tongue Point and north of Taylor Sands where fish used both habitats. At these two stations, the median fish depths were about $10 \mathrm{~m}$.

Estimates of the number of detections of fish in the channel habitats are potentially biased low, particularly at stations where the local bathymetry consisted of both channel and non-channel habitat, because fish may have been swimming in the upper $10 \mathrm{~m}$ of the water column and were miss-assigned to a shallower habitat. Kelly and others (2007) tracked five sub-adults and one adult green sturgeon in the San Francisco Bay Estuary and reported that, when fish were moving directionally between locations, they typically swam in the upper $2 \mathrm{~m}$ of the water column and rarely swam at depths greater than $5 \mathrm{~m}$. In contrast, when the fish were stationary or moving slowly with frequent changes in direction, they typically were associated with the bottom. Like our findings for green sturgeon in the Columbia River Estuary, they reported a high use of shallow regions in San Francisco Bay where bottom depths were less than $10 \mathrm{~m}$ (71 percent of the time). Overall, the fish they tracked swam at depths between 0.3 and $23.3 \mathrm{~m}$.

Green sturgeon that had transmitters equipped with temperature sensors $(N=7)$ inhabited water with temperatures ranging from 9.1 to $22.0^{\circ} \mathrm{C}$ during late May-mid-October in 2010 and 2011. Median water temperatures across all stations ranged from 11.4 to $21.0^{\circ} \mathrm{C}$, similar to those recorded by the temperature loggers. Among estuary areas, fish inhabited water with relatively lower temperatures near the estuary mouth and in relatively higher temperatures east of Point Ellice to Rice Island. In the deeper channel habitat, near the Ilwaco Channel, fish inhabited water with median temperatures ranging from 11.4 to $16.7^{\circ} \mathrm{C}$, whereas east of Point Ellice, predominantly in shallow non-channel habitats, fish typically inhabited water with median temperatures ranging from about 17.0 to $21.0^{\circ} \mathrm{C}$. These results are similar to the water temperatures in rivers and estuaries reported in previous studies for green sturgeon. In the Rogue River, mean monthly temperatures ranged from 8.3 to $22.8^{\circ} \mathrm{C}$ during all months that adult green sturgeon were detected (Erickson and Webb, 2007). In Willapa Bay, Moser and Lindley (2007) reported that green sturgeon entered the estuary when water temperatures in the estuary exceeded coastal water temperatures by at least $2^{\circ} \mathrm{C}$ and were detected at temperatures ranging from 14.0 to $20.0^{\circ} \mathrm{C}$ (Moser and Lindley, 2007). In the San Francisco Bay Estuary, green sturgeon were recorded at temperatures between 14.5 and $20.8^{\circ} \mathrm{C}$ (Kelly and others, 2007). 
Moser and Lindley (2007) suggested that green sturgeon congregate in coastal Oregon and Washington estuaries during the summer in order to benefit from the relatively warmer water temperatures and productive feeding areas where they forage on bivalves, macrocrustaceans, and fish (Moser and others, 2016). Our results as a whole, at least for those fish that migrated upriver in the estuary from Point Ellice to Miller Sands, tend to support this hypothesis. Fish frequently were detected in shallow non-channel habitats in this area, and fish equipped with depth tags most often were detected at depths from 5 to $10 \mathrm{~m}$ bws. The water temperatures inhabited by the fish in this area were also relatively higher than those that occurred closer to the mouth of the estuary for much of the summer.

Our results indicate that green sturgeon do not use Coos Bay as summer habitat, but do use the lower Columbia River from April to October. Green sturgeon that use the lower Columbia River exploit both sandy flats (bottom depth $<10 \mathrm{~m}$ ) and channel habitats (bottom depth $\geq 10 \mathrm{~m}$ ), making them potentially available to dredge equipment entrainment and other dredging effects during their residency within the lower river. Manual tracking of acoustically tagged sturgeon in the lower river could provide more accurate spatiotemporal use of channel habitat and could indicate preferred areas within the channel. For example, our receiver array did not cover the entire shipping channel in the study area because of the limitations of equipment and funding. Green sturgeon may have used a greater proportion of the shipping channel than we observed. Ideally, a positioning system capable of providing two-dimensional locations would be deployed to provide better spatial resolution; however, the logistics of this effort are unrealistic given the commercial and recreational boat traffic.

\section{Acknowledgments}

We would like to thank the following people and their respective agencies who provided assistance during this study: Phillip Dionne and Olaf Langness, Washington Department of Fish and Wildlife; Erick Van Dyke, Oregon Department of Fish and Wildlife; Alicia Seesholtz, California Department of Water Resources; Mary Moser and Michelle Wargo Rub, National Marine Fisheries Service; Robert Chase, U.S. Army Corps of Engineers, and; John Payne, biologist at large. Our science colleagues, Mike Parsley and Bjorn van der Leeuw, also contributed greatly to this study. This report was improved by the reviews of Lisa Wetzel and Matthew Sholtis, U.S. Geological Survey.

\section{References Cited}

Adams, P.B., Grimes, C., Hightower, J.E., Lindley, S.T., Moser, M.L., and Parsley, M.J., 2007, Population status of North American green sturgeon Acipenser medirostris: Environmental Biology of Fishes v. 79, p. 339-356, accessed December 23, 2016, at https://doi.org/10.1007/s10641-0069062-z.

Beeman, J.W., and Perry, R.W., 2012, Bias from false-positive detections and strategies for their removal in studies using telemetry, in Adams, N.S., Beeman, J.W., and Eiler, J.H., eds., Telemetry techniques-A user guide for fisheries research: Bethesda, Maryland, American Fisheries Society, p. 505-518.

Beamesderfer, R.C.P., and Webb, M.A.H., 2002, Green sturgeon status review information: Report of S.P. Cramer and Associates, Inc., for State Water Contractors, Sacramento, California, 46 p., accessed December 5, 2016, at http://www.genidaqs.net/reports/2002/green_sturgeon02.pdf.

Colway, C., and Stevenson, D.E., 2007, Confirmed records of two green sturgeon from the Bering Sea and Gulf of Alaska: Northwest Naturalist, v. 88, p. 188-192, accessed December 22, 2016, at https://doi.org/10.1898/1051-1733(2007)88[188:CROTGS]2.0.CO;2. 
Erickson, D.L., and Hightower, J.E., 2007, Oceanic distribution and behavior of green sturgeon, in Munro, J., Hatin, D., McKeown, K., Hightower, J., Sulak, K.J., Kahnle, A.W., and Caron, F., eds., Symposium on anadromous sturgeon: Bethesda, Maryland, American Fisheries Society Symposium, v. 56, p. 197-211, accessed December 21, 2016, at https://www.fishsciences.net/reports/2007/AFS_Symposium_56_197-211_Oceanic.pdf.

Erickson, D.L., and Webb, M.A.H., 2007, Spawning periodicity, spawning migration, and size at maturity of green sturgeon, Acipenser medirostris, in the Rogue River, Oregon: Environmental Biology of Fishes, v. 79, p. 255-268, accessed December 21, 2016, at https://doi.org/10.1007/s10641-006-9072-x.

Israel, J.A., Bando, K.J., Anderson, E.C., and May, B., 2009, Polyploid microsatellite data reveal stock complexity among estuarine North American green sturgeon (Acipenser medirostris): Canadian Journal of Fisheries and Aquatic Sciences, v. 66, p. 1,491-1,504, accessed December 7, 2016, at https://doi.org/10.1139/F09-091.

Israel, J.A., Cordes, J.F., Blumberg, M.A., May, B., 2004, Geographic patterns of genetic differentiation among collections of green sturgeon: North American Journal of Fisheries Management, v. 24, P. 922-931, accessed December 21, 2016, at https://doi.org/10.1577/M03085.1.

Kammerer, J.C., 1990, Largest rivers in the United States-Fact sheet,: U.S. Geological Survey OpenFile Report 87-242, 2 p., accessed December 27, 2016, at https://pubs.usgs.gov/of/1987/ofr87242/pdf/ofr87242.pdf.

Kelly, J.T., Klimley, A.P., and Crocker, C.E., 2007, Movements of green sturgeon, Acipenser medirostris, in the San Francisco Bay Estuary, California: Environmental Biology of Fishes, v. 79, p. 281-295, accessed December 22, 2016, at https://doi.org/10.1007/s10641-006-0036-y.

Lindley, S.T., Erickson, D.L., Moser, M.L., Williams, G., Langness, O.P., McCovey, B., Jr., Vogel, D., Pinnix, W., Kelly, J.T., Heublein, J.C., and Klimley, A.P., 2011, Electronic tagging of green sturgeon reveals population structure and movement among estuaries: Transactions of the American Fisheries Society, v. 140, p. 108-122, accessed December 8, 2016, at https://www.tandfonline.com/doi/citedby/10.1080/00028487.2011.557017.

Lindley, S.T., Moser, M.L., Erickson, D.L., Belchik, M., and Welch, D.W., 2008, Marine migration of North American green sturgeon: Transactions of the American Fisheries Society, v. 137, p. 182-194, accessed December 21, 2016, at https://doi.org/10.1577/T07-055.1.

Miller, D.J., and Lea, R.N., 1972, Guide to the coastal marine fishes of California: Fish Bulletin 157, Californian Department of Fish and Game, 235 p., accessed December 22, 2016, at http://escholarship.org/uc/item/6s04v367.

Monaco, M., Lowery, T., and Emmett, R.,1992, Assemblages of U.S. West Coast estuaries based on the distribution of fishes: Journal of Biogeography, v. 19, p. 251-267, accessed December 27, 2016, at https://doi.org/10.2307/2845450.

Moser, M.L., Israel, J.A., Neuman, M., Lindley, S.T., Erickson, D.L., McCovey, B.W. and Klimley, A.P., 2016, Biology and life history of green sturgeon (Acipenser medirostris Ayres, 1854)—State of the science: Journal of Applied Ichthyology, v. 32, p. 67-86, accessed December 21, 2016, at https://doi.org/10.1111/jai.13238.

Moser, M.L., and Lindley, S.T., 2007, Use of Washington estuaries by subadult and adult green sturgeon: Environmental Biology of Fishes, v. 79, p. 243-253, accessed December 21, 2016, at https://doi.org/10.1007/s10641-006-9028-1.

Moyle, P.B., 2002, Inland fishes of California: Berkeley, University of California Press, 502 p.

National Oceanic and Atmospheric Administration, 2006, Endangered and threatened wildlife and plants-Threatened status for Southern Distinct Population Segment of North American green sturgeon: Federal Register, v. 71, no. 67, p. 17,757-17,766, accessed December 5, 2016, at http://www.nmfs.noaa.gov/pr/pdfs/fr/fr71-17757.pdf. 
National Oceanic and Atmospheric Administration, 2009, Endangered and threatened wildlife and plants-Final rulemaking to designate critical habitat for the threatened Southern Distinct Population Segment of North American green sturgeon: Federal Register, v. 74, no. 195, p. 52,300-52,351, accessed December 5, 2016, at http://www.nmfs.noaa.gov/pr/pdfs/fr/fr74-52300.pdf.

National Oceanic and Atmospheric Administration, 2014, 2014 Informal status review for the Northern Distinct Population Segment of the North American green sturgeon (Acipenser medirostris): Prepared by Phaedra Doukakis under contract with National Oceanic and Atmospheric Administration, 26 p., accessed December 5, 2016, at http://www.fisheries.noaa.gov/pr/species/documents/20nov2014_ndps_greensturgeon_review_final. pdf.

Parsley, M.J., 2009, Detections of acoustic-tagged green sturgeon in Baker Bay on the lower Columbia River during September-November 2008: U.S. Geological Survey Open-File Report 2009-1026, 10 p., accessed December 5, 2016, at https://pubs.usgs.gov/of/2009/1026/.

R Core Team (2017). R: A language and environment for statistical computing. R Foundation for Statistical Computing, Vienna, Austria. URL https://www.R-project.org/.

Rosales-Casian, J.A., and Almeda-Jaurgui, C., 2009, Unusual occurrence of a green sturgeon, Acipenser medirostris, at El Socorro, Baja California, Mexico: California Cooperative Oceanic Fisheries Investigations Reports, v. 50, p. 169-171, accessed December 22, 2016, at http://calcofi.org/publications/calcofireports/v50/169-171_Rosales.pdf.

Rumrill, S.S., 2006, The ecology of the South Slough Estuary-Site profile of the South Slough National Estuarine Research Reserve: Salem, Oregon, National Oceanic and Atmospheric Administration/Oregon Department of State Lands Technical Report, 238 p.

Schreier, A., Langness, O.P., Israel, J.A., and Van Dyke, E., 2016, Further investigation of green sturgeon (Acipenser medirostris) distinct population segment composition in non-natal estuaries and preliminary evidence of Columbia River spawning: Environmental Biology of Fishes, v. 99, p. 1,021-1,032, accessed December, 21, 2016, at https://doi.org/10.1007/s10641-016-0538-1.

Sherwood, C.R., Jay, D.A., Harvey, R. B., Hamilton, P., and Simenstad, C.A., 1990, Historical changes in the Columbia River Estuary: Progress in Oceanography, v. 25, p. 299-252, accessed February 22, 2017, at https://doi.org/10.1016/0079-6611(90)90011-P.

U.S. Army Corps of Engineers, 2015, Columbia River Federal navigation channel operations and dredged material placement network update-Final environmental assessment: U.S. Army Corps of Engineers, 55 p. 


\section{Appendix A. Dates When Acoustic-Receiver Stations in the Detection Array Were Operational in the lower Columbia River Estuary, Washington and Oregon, 2010-11.}

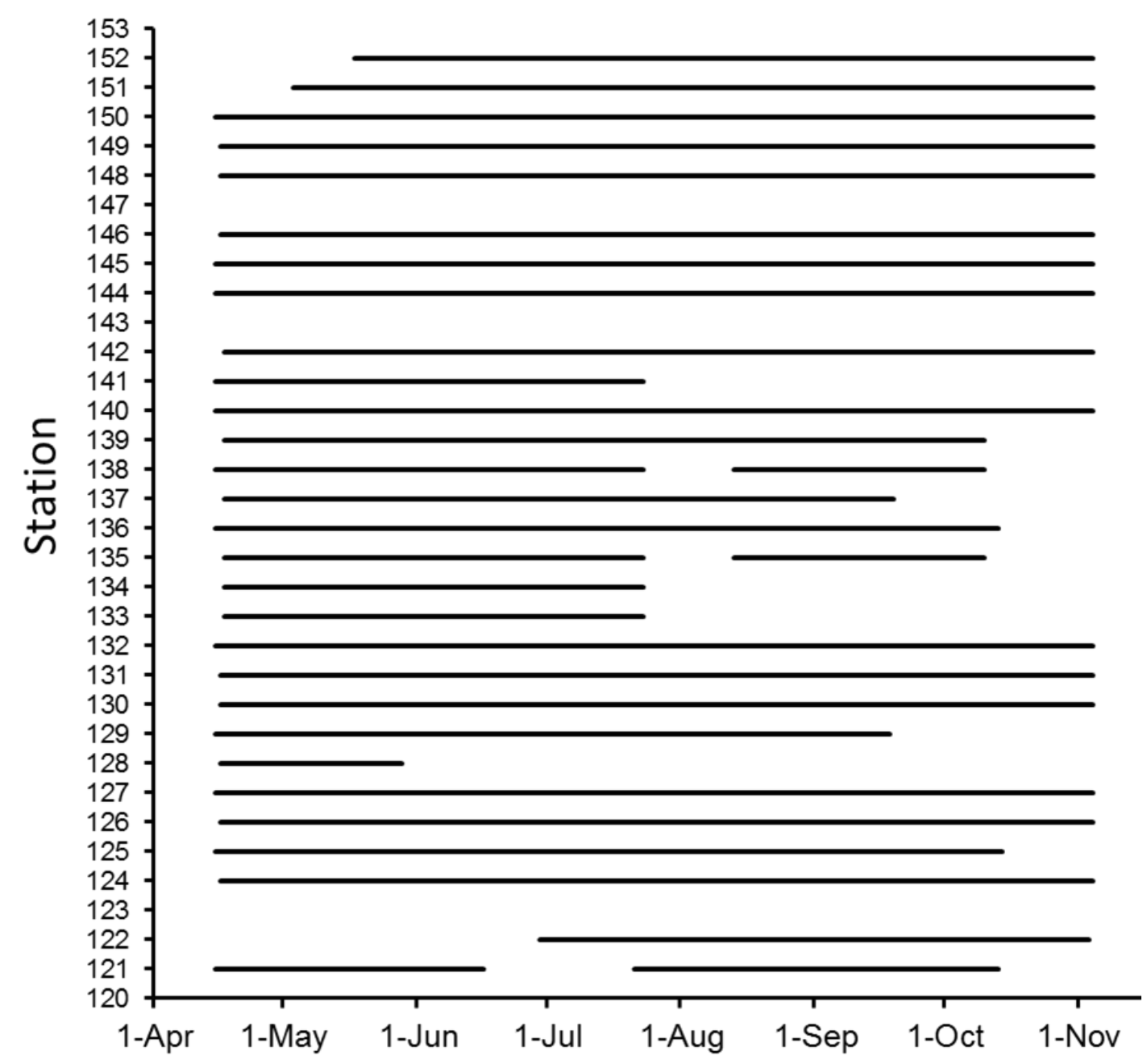

Figure A1. Graphs showing dates on which acoustic-receiver stations in the detection array were operational in the lower Columbia River Estuary, Washington and Oregon, 2010. 


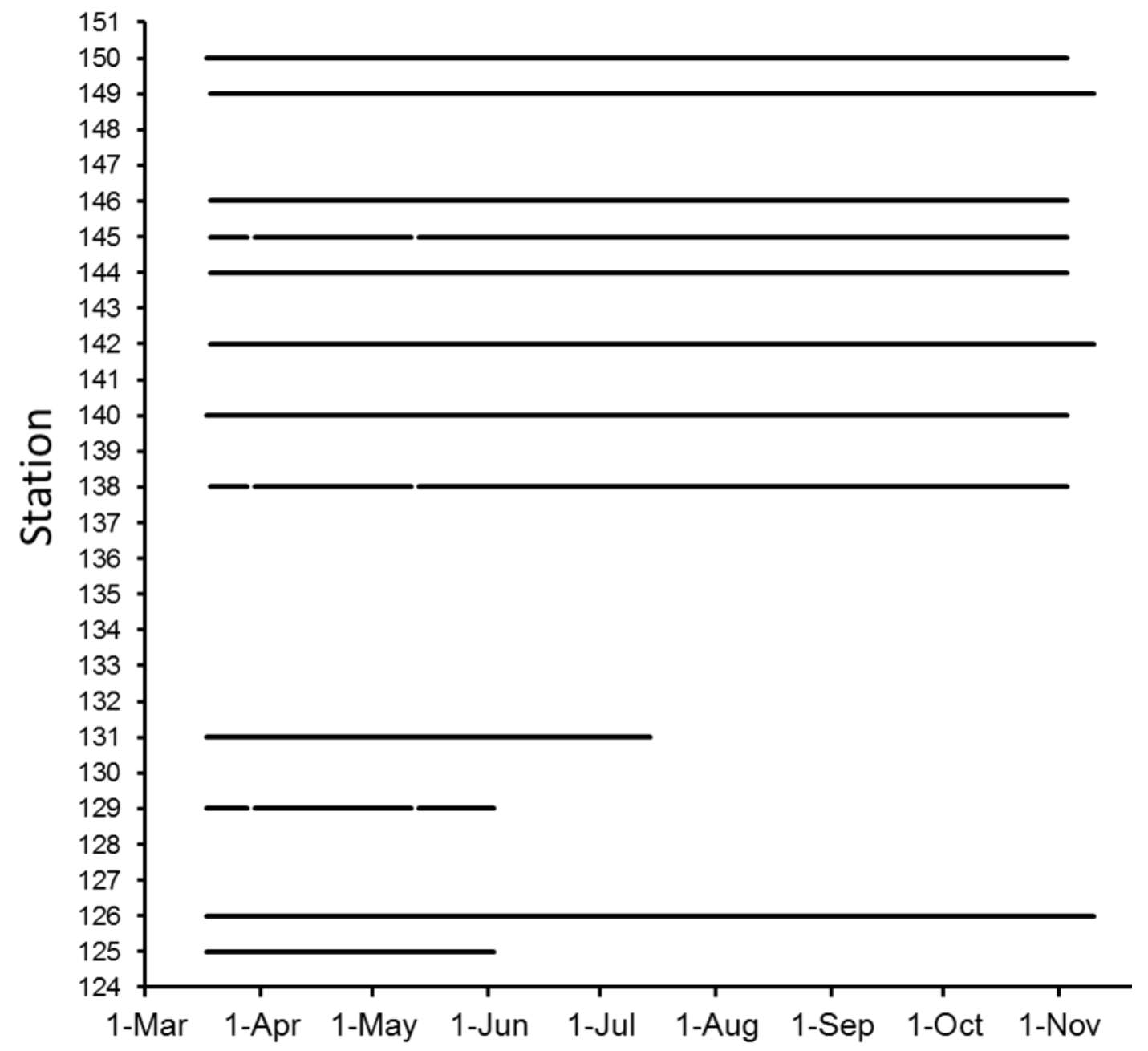

Figure A2. Graph showing dates on which acoustic-receiver stations in the detection array were operational in the lower Columbia River Estuary, Washington and Oregon, 2011. 
Publishing support provided by the U.S. Geological Survey

Science Publishing Network, Tacoma Publishing Service Center

For more information concerning the research in this report, contact the Director, Western Fisheries Research Center

U.S. Geological Survey

6505 NE 65th Street

Seattle, Washington 98115

https://wfrc.usgs.gov/ 
